\title{
GROTY BRONI DRZEWCOWEJ O CECHACH SKANDYNAWSKICH W KULTURZE LUBOSZYCKIEJ
}

SŁowa KLuCzowe: groty; uzbrojenie; kultura luboszycka

KEYwords: shafted weapons' heads; weapons; Luboszyce culture

Obecność uzbrojenia o cechach skandynawskich w inwentarzu kultury luboszyckiej została już odnotowana w literaturze bronioznawczej dotyczącej okresu rzymskiego ${ }^{1}$. Niemniej, z wyjątkiem dosyć ogólnikowych uwag na temat tego zjawiska, brakuje dokładnej jego analizy czy chociażby kompletnego skatalogowania zabytków o konotacjach północnoeuropejskich ${ }^{2}$. Niniejsza praca ma na celu poprawienie tej sytuacji w zakresie grotów broni drzewcowej.

W celu poprawnego wskazania tego rodzaju zabytków potrzebne jest sformułowanie odpowiednich kryteriów identyfikacji. Jako najważniejszą cechę ,skandynawską" wśród grotów bez zadziorów wskazać należy charakterystyczne

${ }^{1}$ Chcielibyśmy w tym miejscu gorąco podziękować prof. Marianowi Głoskowi, promotorowi dysertacji Karola Demkowicza, z której pochodzi większość materiałów wykorzystanych w niniejszym artykule, a także prof. Grzegorzowi Domańskiemu za poświęcenie swojego czasu na bezcenne konsultacje, dotyczące zawiłej problematyki kultury luboszyckiej. Wdzięczność jesteśmy winni również: dr Heino Neumayerowi z Museum für Vor- und Frühgeschichte Berlin, dr Jasperowi von Richthofenowi z Kulturhistorisches Museum Görlitz, dr Silke Schwarzländer z Brandenburgisches Landesamt für Denkmalpflege Wünsdorf oraz dr Reginie Smolnik z Landesamt für Archäologie Sachsen in Dresden za zgodę na przeprowadzenie kwerendy w podlegających im placówkach i oddziałach oraz udostępnienie do publikacji znalezionych w nich materiałów. Chcielibyśmy również podziękować pracownikom tych instytucji za uprzejmą i trudną do przecenienia pomoc w korzystaniu z tych zasobów.

${ }^{2}$ Określenia „skandynawskie” i „północnoeuropejskie” będą używane w artykule wymiennie, przy czym mamy świadomość, że nie są one zupełnie tożsame. Niemniej, zabieg ten dla badań nad okresem rzymskim wydaje sie być uzasadniony, zważywszy na rozpowszechnione wśród jego badaczy pojęcie „północnoeuropejskiego Barbaricum”, obejmującego właśnie Półwysep Skandynawski, Półwysep Jutlandzki, Wyspy Duńskie, Gotlandię i Olandię. 
taliowanie liścia. Krawędzie tnące są charakterystycznie zagięte do wewnątrz, najczęściej na ok. 2/3 długości liścia licząc od strony tulei. Takie ukształtowanie brzegów występuje również w grotach kultury przeworskiej, typu I wg P. Kaczanowskiego (1995: 11-14, tabl. I-V.2), jednak formy te wychodzą $\mathrm{z}$ użytku w fazie $\mathrm{C} 1 \mathrm{a}$. W kręgu północnoeuropejskim egzemplarze $\mathrm{z}$ taliowanym liściem funkcjonują od fazy B2 do końca okresu rzymskiego.

Często jednak wskazówką pozwalającą na rozpoznanie skandynawskich grotów jest po prostu zbliżenie proporcji i ogólnej sylwetki grotu do egzemplarzy północnoeuropejskich i jednoczesne niewpasowanie się w klasyfikację grotów kultury przeworskiej. Słaby stan zachowania czy udokumentowania analizowanych artefaktów czasami powoduje, że poprawna identyfikacja interesujących nas egzemplarzy jest poważnie utrudniona.

Sytuacji nie ułatwia również stan badań nad kulturą luboszycką. Znaczna część jej materiału zabytkowego to znaleziska luźne pochodzące z przypadkowych odkryć, dokonywanych przy okazji intensywnej industrializacji wschodnich terenów II i III Rzeszy. Jeszcze większy procent zabytków został pozyskany w II połowie XIX i I poł. XX wieku na skutek amatorskich lub półprofesjonalnych badań starożytników niemieckich (Domański 1979: 9-12; 2010a: 13-18; 2010b: 240). Nazbyt często nie byli oni w stanie należycie udokumentować bardzo skomplikowanej niekiedy sytuacji na cmentarzyskach luboszyckich, co prowadziło do przemieszania zespołów. $Z$ tego powodu wyposażenie większości z odkrytych w tym czasie „pochówków” należy traktować jako egzemplarze luźne z cmentarzyska. Na szczęście skandynawskie groty broni drzewcowej są same w sobie zabytkami o dużej czułości chronologicznej i często można je datować stosunkowo precyzyjnie bez pomocy ich kontekstu.

Dobrym przykładem jest przypadek grobu jamowego z Dornswalde, Lkr. Teltow-Fläming (Brather 2001: 89-103) (nr 3, tabl. IV.1). Oprócz grotu broni drzewcowej bez zadziorów zawierał on $\mathrm{m}$. in. sprzączkę typu D11 i G3 wg R. Madydy-Legutko (1986: 27-28, 46-47, Taf. 8.11, 13.3), dwa fragmenty zapinki (lub zapinek) A162 oraz ułamane okucie końca pasa typu J wg K. Raddatza (1957: 88-104, Abb. 2). Elementy te pozwalaja jedynie na szerokie datowanie w ramach okresu C1-C2, na szczęście sam grot włóczni, należący do typu 15 wg J. Ilkjaera (1990: 95-109) ma precyzyjniejszą chronologię mieszczącą się w ramach fazy $\mathrm{C} 1^{3}$.

\footnotetext{
${ }^{3}$ Groty typu 15 zaliczane są przez J. Ilkjaera do grupy 5 skandynawskich grobów z uzbrojeniem, datowanej przez tego badacza na początek fazy C1b. Można jednak zauważyć, że nawet on wymienia szereg tego typu grotów, znalezionych w grobach zawierających wyposażenie adekwatne dla fazy $\mathrm{Cl}$ a. Należy również wspomnieć, że według tego badacza początek $\mathrm{C} 1 \mathrm{~b}$ w Skandynawii przypada na ok. 200/210; z tak wczesnym datowaniem fazy C1b w Skandynawii
} 
W grobie jamowym nr 4b z cmentarzyska w Horno, Lkr. Spree-Neiße (Schwarzländer 2006: 76-77, Abb. 11-13). wystapił egzemplarz typu 4 - mało spektakularny okaz o liściu z ledwo widocznym taliowaniem oraz stosunkowo długa, zwężającą się ku wylotowi tulejką o przekroju w kształcie czworokąta z zaokraglonymi bokami (nr 10, tabl. I.2). Razem z omawianym zabytkiem wystąpiły $\mathrm{m}$. in.: imacz z niewyodrębnionymi płytkami typu pośredniego między V1 a W wg N. Zielinga (1989: 218-219, 223-225, Taf. 30.1-2, 31.1-2), miecz typu Folkeslunda-Zaspy wg M. Biborskiego (2006: 193-200), zawieszka pochwy miecza typu IIID1 wg C. von Carnap-Bornheima (1991: 43-44, Taf. 29.289-291) oraz umbo z wyodrębnionym kołnierzem typu P wg N. Zielinga (1989: 137-138, Taf. 14.4). Ostatni z wymienionych artefaktów datowany jest na okres $\mathrm{C} 1 \mathrm{~b}-\mathrm{C} 2$, przy czym wspomniana zawieszka występuje najpóźniej $\mathrm{w}$ fazie $\mathrm{C} 1$. Miecz również jest formą używaną w tym odcinku czasowym. Na tej podstawie przyjąć można bezpiecznie chronologię grobu, a co za tym idzie grotu, na fazę C1b.

Z tego samego okresu pochodzi grób jamowy (Geisler 1970: 133-138, Abb. 1-15; Leube 1975: 123, Taf. 28) z Jessern, Lkr. Dahme-Spreewald (nr 11, tabl. V.1). Zawierał on miecz typu Folkeslunda-Zaspy wg M. Biborskiego (2006: 193-200), fragment zawieszki pochwy miecza typu IIID1 wg C. von CarnapBornheima (2006: 43-44, Taf. 29.289-291), topór z trójkątnymi wąsami oraz grot bez zadziorów typu 14 wg J. Ilkjaera (1990: 111-118). Jak już zostało wspomniane, dwa pierwsze znaleziska datować należy na fazę $\mathrm{C} 1$. Interesująca nas część broni drzewcowej spotykana jest w kontekstach skandynawskich w okresie $\mathrm{C} 1 \mathrm{~b}-\mathrm{C} 2$, jednak pozostałe wyposażenie grobu z Jessern zawęża chronologię zespołu do wcześniejszego odcinka.

Podobną sytuację można zaobserwować w związku z popielnicowym grobem nr 1 (nr 15, tabl. III.4) z Niewitz, Lkr. Dahme-Spreewald (Jentsch 1895: 126; Marschalleck 1944: 139, Abb. 46; Leube 1975: 124, Taf. 27.1-2; Archiwum...). W jego skład wchodził m. in. topór z wąsami u osady oraz okucia wiaderka, a także niemożliwy do zidentyfikowania na podstawie publikacji grot bro-

nie zgadzał się K. Godłowski (1988: 33), podczas gdy w na kontynencie moment ten wyznaczany jest na lata 220/230 (K. Godłowski 1988: 43). Przy założeniu poprawności tych cezur groty datowane na początek fazy $\mathrm{Clb}$ w północnoeuropejskim Barbaricum teoretycznie mogłyby wejść w skład środkowoeuropejskich zespołów pochodzących jeszcze z końca fazy C1a. Niejednoznaczność chronologii względnej omawianych zabytków zauważyli już J. Bemmann i G. Hahne (1994: 302), opowiadając się za ich szerszym, bo obejmującym fazę C1 datowaniem. Również w mojej ocenie ta ostrożna opinia wydaje się prawidłowa z tym zastrzeżeniem, że groty typu $15 \mathrm{w}$ przeważającej mierze łączyć należy z późniejszym odcinkiem fazy C1, przy czym moment ich pojawienia się przesunąć można na schyłek fazy C1a. 
ni drzewcowej bez zadziorów. Dzięki rysunkowi z prywatnego archiwum M. Jahna udało się ustalić, że egzemplarz ten, to w istocie okaz typu 17 wg J. Ilkjaera (1990: 120-125), datowany na fazę C1b.

W dalszej kolejności wymienić należy grot typu 4 wg J. Ilkjaera (1895: 48-50) z grobu popielnicowego $\mathrm{nr}$ 4a (Schwarzländer 2006, s. 75-76, Abb. 9-11) z cmentarzyska w Horno, Lkr. Spree-Neiße (nr 9, tabl. I.1). Zarys liścia nie pozostawia wątpliwości co do związków zabytku z kręgiem północnoeuropejskim. Pochówek był bogato wyposażony $\mathrm{m}$. in. w topór $\mathrm{z}$ wyodrębnionym młotkiem i symetrycznym ostrzem, skandynawskie krzesiwo iglicowe, krzesiwo sztabkowate, pilnik, sprzączkę do pasa typu D29 wg R. Madydy-Legutko (1986: 32-33, taf. 10.29), brązowe okucie końca pasa typu O15 wg K. Raddatza (1957: $87-88$, abb. 1) oraz mały, wykonany na kole pucharek na nóżce. Najbardziej interesujący z tego zbioru jest ostatni z wymienionych artefaktów - moment pojawienia się w kulturze luboszyckiej ceramiki toczonej na kole garncarskim jest nadal przedmiotem debat (Schuster 1998: 203-214; 2008: 131-143; Domański 2008: 145-163). Można stwierdzić, że znaczna większość tego typu materiału pochodzi z faz C2 i C3 (Domański 1979: 77, 2008: 158). Z kolei okucie końca pasa reprezentuje typ pojawiający się w kulturze przeworskiej najczęściej w fazie $\mathrm{C} 1$, niemniej znane są podobne znaleziska ze środkowoeuropejskiego Barbaricum datowane na fazę $\mathrm{C} 2$. Chronologia sprzączki określana jest przez R. Madydę-Legutko na okres C1b-C2 i tak też w mojej ocenie należy datować zespół. Sam grot nie mógł być w analizie chronologicznej pomocny, ponieważ egzemplarze typu 4 spotykane są przez cały okres wczesnorzymski, aż do fazy C2 (Ilkjaer 1990: 50).

Większość pozostałych wczesnych grotów broni drzewcowej o cechach północnoeuropejskich z kultury luboszyckiej jest niestety znaleziskami luźnymi. Do grupy tej zalicza się należący do typu 15 wg J. Ilkjaera (1990: 95-109) (a co za tym idzie datowany na fazę C1) okaz z Hartmannsdorf, Lkr. DahmeSpreewald (Jahn 1925: 190, 193, Abb. 1.1; Leube 1975: 123; Archiwum...) (nr 8, tabl. IV.2). Podobną chronologię mają dwa inne, bardzo szczególne groty: okaz z Dziwiszowej, pow. Żagań (Tackenberg 1925: 55; Archiwum...) (nr 4, tabl. III.1) oraz ze Straupitz, Lkr. Dahme-Spreewald (Weineck 1896: 321-350; Dohnsack 1940: 1087-1088, Taf. 449.5, 450.2; Leube 1975: 125) (nr 24, tabl. III.2). Precyzyjne sklasyfikowanie pierwszego z wymienionych było możliwe jedynie dzięki rysunkowi z archiwum M. Jahna. Przedstawiony na nim grot ma liść o szczególnym, sześciokątnym przekroju, co plasuje go w ramach typu 7 wg J. Ilkjaera (1895: 73-74). Forma ta jest rzadko spotykana nawet w Skandynawii - znana

\footnotetext{
${ }^{4}$ Stary katalog Museum für Vor- und Frühgeschichte Berlin, nr inw. Ie 1199.
} 
jest jedynie ze stanowisk bagiennych w Vimose i Illerup. Drugi z wymienionych grotów bez zadziorów zaliczyć należy do typu $10 \mathrm{wg}$ J. Ilkjaera (1895: 73-74). Ramy chronologiczne tej grupy rozciagają się od fazy B2b do C1. Niemniej analizowany egzemplarz zaopatrzony jest $\mathrm{w}$ ornament na liściu (problematyka z nim związana zostanie omówiona w dalszej części pracy), który ogranicza datowanie do odcinka późnorzymskiego.

Do tego samego typu zaliczyć należy znalezisko z tzw. grobu 3 ze zniszczonego cmentarzyska (Schulz W. 1931: 67, Taf. XII.1) w Stolzenhain, Lkr. Elbe-Elster (nr 23, tabl. III.3). Materiał z tej nekropolii ma metrykę zamykająca się w okresie od $\mathrm{C} 1$ do $\mathrm{C} 2$ - ogranicza ona datowanie grotu do fazy $\mathrm{C} 1$.

W taki sam sposób należy określić chronologię innego grotu $\mathrm{z}$ tego stanowiska, pochodzącego z tzw. grobu 1 ( $\mathrm{nr} 22$, tabl. VI.3) - tym razem zaopatrzonego w zadziory (Schulz W. 1931: 64, Taf. XI.1). Jest on zbliżony do typu $8 \mathrm{wg}$ J. Ilkjaera (1990: 187-197), używanego od fazy B2b do C1, ze szczególnym nasileniem $\mathrm{w}$ fazie $\mathrm{C} 1 \mathrm{~b}$. Również i w tym przypadku ramy czasowe stanowiska ograniczają datowanie do późniejszego odcinka występowania omawianej formy.

Stosunkowo duży zbiór grotów bez zadziorów pochodzi z okresu C1-C2. Mowa tutaj o dwóch egzemplarzach (nr 16, 17, tabl. II.1-2) ze zniszczonego cmentarzyska w Prieschka, Lkr. Elbe-Elster (Gandert 1930: 174; Archiwum...) $)^{5}$, oraz o jednym luźnym znalezisku (nr 12, tabl. I.3) z Kosilenzien, Lkr. Elbe-Elster (Gandert 1930: 174; Schulz W. 1931: 62; Domański 1979: 238; Archiwum...). Wszystkie należą do typu 4 wg J. Ilkjaera (1990: 48-50) i posiadają liście o wgiętych krawędziach, a drugi z wymienionych okazów (nr 17) w chwili znalezienia miał widoczny ornament na tulejce.

Węższe datowanie mają trzy znaleziska typu 14 wg J. Ilkjaera (1990: 111118). Pierwszy z nich (Jentsch 1889: 346, fig. 5; 1895: 111, fig. 47) pochodzi z tzw. grobu 1 z nekropolii w Grabicach, pow. Krosno Odrzańskie ${ }^{6}$ (nr 7, tabl. IV.3). Wyposażenie tego pochówku to w rzeczywistości przemieszany materiał z kilku obiektów, dlatego też interesujący nas grot traktować należy jako znalezisko luźne z cmentarzyska. Drugi egzemplarz również pochodzi z przemieszanego grobu, tzw. 1 (Schulzt W. 1931: 64, Taf. XI.3, XIII.1) ze wspominanego już stanowiska w Stolzenhain, Lkr. Elbe-Elster (nr 20, tabl. V.2). Egzemplarz ten według informacji zawartych w przedwojennej publikacji pokryty był ornamentem. Trzeci okaz znaleziono na tej samej nekropolii (Schultz 1931: 64, Taf. XI.10), rzekomo w tym samym (przemieszanym) pochówku (nr 21, tabl. V.3)

\footnotetext{
${ }^{5}$ Stary katalog Museum für Vor- und Frühgeschichte Berlin, nr inw. Ig 3925b, Ig 3925c.

${ }^{6}$ Prywatne archiwum prof. G. Domańskiego.
} 
- na fotografii widniejącej w przedwojennej publikacji można dojrzeć, oprócz taliowania liścia, żeberko biegnące przez całą jego długość. Datowanie wszystkich trzech okazów ustalone jest na podstawie chronologii typu 14 i rozciaga się na okres $\mathrm{C} 1 \mathrm{~b}-\mathrm{C} 2$.

$\mathrm{Na}$ fazę $\mathrm{C} 2$ datować można bogaty grób jamowy z Falkenberg, Lkr. Märkisch-Oderland (Pescheck 1939: 14-16, Abb. 1). W jego inwentarzu znalazło się m. in. półkuliste umbo typu O wg N. Zielinga (1989: 135-136, Taf. 14.1-1) i grot bez zadziorów typu 9 wg J. Ilkjaera (1990: 67) (nr 5, tabl. VII.2). Datującym elementem okazał się grot z zadziorami typu 3 wg J. Ilkjaera (1990: 223), charakteryzujący się bardzo długą tuleją (nr 6, tabl. VII.1). Podobne znalezisko pochodzi z omawianego wcześniej cmentarzyska (Gandert 1930: 174) w Prieschka, Lkr. Elbe-Elster ${ }^{7}$ (nr 18, tabl. VII.3), niestety w tamtym przypadku jest to okaz pozbawiony zespołu. Na fazę $\mathrm{C} 2$ datować należy również inne luźne znalezisko, tym razem grotu bez zadziorów typu 14 wg J. Ilkjaera (1990: 111-118) pochodzące z Ullersdorf, Lkr. Görlitz (Schulzt H. A. 1937: 30-31, Abb. 9; Meyer 1971: 205, Abb. 120.1) (nr 25, tabl. V.4). Na sprecyzowanie chronologii okazu wpływ miało miejsce znalezienia - grot należy łączyć z grupą górnołużycką kultury luboszyckiej, której okres funkcjonowania ogranicza się najprawdopodobniej do faz $\mathrm{C} 2-\mathrm{C} 3$.

Inny późny grot pochodzi z tego samego regionu - mowa tutaj o znalezisku luźnym (Schulzt H. A. 1937: 29, abb. 9) z okolic Bautzen, Lkr. Bautzen (nr 1, tabl. V.1) należącym do typu 28 wg J. Ilkjaera (1990: 1390). W tym przypadku czas trwania osadnictwa na terenach Górnych Łużyc (C2-C3) pokrywa się $\mathrm{z}$ datowaniem powyższego rodzaju grotów, i tak tez należy określić chronologię omawianego egzemplarza.

Pewne trudności interpretacyjne napotykamy w związku $\mathrm{z}$ kolejnym grotem bez zadziorów typu $28 \mathrm{wg}$ J. Ilkjaera, znalezionym na zniszczonym cmentarzyska (Schultz W. 1931: 75, Taf. XVIII.3; Meyer 1971: 260, Abb.147.1) w Kranichau, Lkr. Nordsachsen (nr 13, tabl. VI.2). W jego przypadku niestety nie mamy zupełnej pewności w kwestii przynależności artefaktu do kultury luboszyckiej. Stanowisko, z którego pochodzi, leży na lewym brzegu Łaby, tj. na samych peryferiach zasięgu interesującej nas jednostki taksonomicznej. Na obszarze tym trudno jest nakreślić jasną linię podziału pomiędzy poszczególnymi pochówkami „luboszyckimi” a obiektami należącymi raczej do kręgu nadłabskiego. Cmentarzysko w Kranichau, na którym odnaleziono grot, dostarczyło pewnej ilości ceramiki charakterystycznej dla kultury luboszyckiej, niemniej sam grot (jak i inne elementy uzbrojenia) pozbawiony jest zespołu. $\mathrm{Z}$ tego też

\footnotetext{
${ }^{7}$ Stary katalog Museum für Vor- und Frühgeschichte Berlin, nr inw. Ig 3925e.
} 
powodu przynależność tego okazu do kultury będącej przedmiotem tego artykułu nie może być uznana za przesądzona. Materiał zabytkowy z Kranichau datowany jest na okres późnorzymski, podczas gdy chronologia gotów typu 28 zamyka się w fazach C2 i C3.

Dwa groty o formie typowo skandynawskiej z inwentarza kultury luboszyckiej pokryte są charakterystycznym ornamentem wytłaczanych kresek. Mowa tutaj o grocie (Weineck 1896: 321-350; Kossina 1905: 372; Leube 1975: 125) ze Straupitz, Lkr. Dahme-Spreewald (nr 24, tabl. III.2, IX.2) oraz z tzw. grobu 1 (Schulz 1931: 64, Taf. XI.3, XIII.1) ze Stolzenhain, Lkr. Elbe-Elster (nr 20, tabl. V.2, IX.1). Pierwszy z wymienionych jest obecnie niedostępny dla badaczy, a drugi zaginął. $\mathrm{Z}$ dostępnych informacji na ich temat nie można odtworzyć w sposób dokładny wzoru zdobienia. Wiemy jednak, że ornament zawarty był w półkolistych polach umieszczony po obydwu stronach żeberka. W przypadku artefaktu ze Straupitz zdobione powierzchnie wypełnione są układem prostopadłych, równoległych i ukośnych kresek. Szczegóły ułożenia kresek w polach widniejących na liściu grotu ze Stolzenhain niestety nie są znane.

Wybijany ornament $\mathrm{w}$ półkolistych polach pojawił się w Skandynawii już w fazie B1. Z tych terenów został on przejęty przez ludność kultury przeworskiej najprawdopodobniej w fazie B2 (Kaczanowski 1988: 60-61; Kontny 2008: 152-155). W okresie wczesnorzymskim wypełnienie pól stanowiły równoległe względem siebie i osi symetrii grotu kreski, tworzące tzw. ornament ściegowy. Niemniej, w okresie późnorzymskim (dokładniej w fazach C1-C2) pola często zapełniane były kreskami tworzącymi również bardziej skomplikowany wzór (Ilkjaer 1990:32-33), którego przykładem może być zdobienie okazu ze Straupitz oraz najprawdopodobniej to z egzemplarza ze Stolzenhain. Całą serię podobnie ornamentowanych grotów znaleziono w depozytach z Illerup (Ilkjaer 1990: 96) i Nydam z Danii (Bemmann, Bemmann: 1998: 154-183, Taf. 71-115).

Pewnego pokrewieństwa do wyżej wymienionych przykładów można doszukiwać się w kolejnym okazie z terenów kultury luboszyckiej. Na jednym z grotów (Gandert 1930: 174) z Prieschka, Lkr. Elbe-Elster ${ }^{8}$ (nr 17, tabl. II.2, XI.3) widniał ornament wybijanych kresek ułożonych rzędami na tulei grotu, na odcinku jej przejścia w liść (Kontny 2008: 157, ryc. 8; Archiwum...). Niestety zdobienie to nie zachowało się do naszych czasów. Takie umiejscowienie ornamentu jest rzadko spotykane - przywołać można jako analogię grot nr 875 z Nydam w Danii (Bemmann, Bemmann: 1998: 179, Taf. 98).

Przy okazji omawiania grotów o cechach skandynawskich w kulturze luboszyckiej warto poświęcić uwagę charakterystycznym formom przejścia

\footnotetext{
${ }^{8}$ Stary katalog Museum für Vor- und Frühgeschichte Berlin, nr inw. Ig 3925c.
} 
tulei w liść występujących na wielu zabytkach tej kategorii. Znalezisko z Dornswalde, Lkr. Teltow-Fläming (Brather 2001: 89-93) (nr 3, tabl. IV.1) posiadało dosyć szczególny jego wariant, mocno rozpowszechniony w Skandynawii - tuleja skośnie schodzi do płaszczyzny liścia, przy czym jej powierzchnia na tym przejściowym odcinku jest spłaszczona i w przekroju przypomina prostokąt. Na tym samym odcinku bierze swój początek precyzyjnie wykute żeberko - w efekcie powstaje wrażenie, że wchodzi ono głęboko na tulejkę.

Zbliżoną konstrukcję można zaobserwować na egzemplarzu z grobu 1 (Jentsch 1895: 126, Marschalleck 1944: 139; Leube 1975: 124, Taf. 27.1-2) z Niewitz, Lkr. Dahme-Spreewald (Archiwum...) (nr 15, tabl. III.4). Wyodrębnienie żeberka osiagnięto jednak w tym przypadku poprzez wykucie lub wyszlifowanie dwóch rowków po obu jego stronach. Ponadto początek żeberka i wspomniane rowki cofnięte były głęboko na tulejkę w znacznym oddaleniu od liścia. Podobny detal (choć nie tak badzo przesunięty do tyłu) można zaobserwować na silnie zniszczonym znalezisku z Brunsberg z Norwegii (Bermmann, Hahne 1994: 422, Abb. 62).

$\mathrm{Na}$ egzemplarzach luboszyckich najczęściej można zaobserwować wzmiankowane wcześniej, charakterystyczne, zbliżone do stożka lub ostrosłupa przejście tulejki w liść. Tak ukształtowany element można dostrzec na grotach z: Falkenberg, Lkr. Märkisch-Oderland (Pescheck 1939: 14-16, Abb. 1) (nr 5, tabl. VII.2), Grabic, pow. Krosno Odrzańskie (Jentsch 1889: 346, Fig. 5; 1895: 111, Fig. 47) (nr 7, tabl. IV.3), Hartmannsdorf, Lkr. Dahme-Spreewald (Jahn 1925: 190, 193, Abb.1.1; Leube 1975: 123; Archiwum...) (nr 8, tabl. IV.2), ob. 4b (nr 10, tabl. I.2) z Horno (Schwarzländer 2006: 76-77, Abb. 11-13), Lkr. SpreeNeiße, Kosilenzien, Lkr. Elbe-Elster (Gandert 1930: 174; Schulz W. 1931: 62; Domanski 1979: 238; Archiwum...) (nr 12, tabl. I.3) oraz na dwóch egzemplarzach z Prieschka, Lkr. Elbe-Elster (Gandert 1930: 174) $)^{10}$ (nr 16, 17, tabl. II.1-2). Oznacza to, że spośród 19 grotów bez zadziorów o formie ewidentnie nawiązującej do okazów północnoeuropejskich, aż 7 egzemplarzy (czyli 37\%) ${ }^{11}$ zaopatrzonych jest w stożkowate przejście tulei w liść.

W inwentarzu kultury luboszyckiej znajdują się również trzy groty ze wspomnianym rodzajem przejścia tulei w liść, lecz pozbawione jednoznacznych cech skandynawskich. Niemniej, ich proporcje nie mieszczą się w żadnym z późnorzymskich typów w klasyfikacji $\mathrm{P}$. Kaczanowskiego. W systematyce

\footnotetext{
${ }^{9}$ Prywatne archiwum prof. G. Domańskiego.

${ }^{10}$ Stary katalog Museum für Vor- und Frühgeschichte Berlin, nr inw. Ig 3925b, Ig 3925c.

${ }^{11} \mathrm{~W}$ zestawieniu tym wzięto pod uwagę luźny grot z Kranichau, Lkr. Nordsachsen.
} 
J. Ilkjaera wszystkie można zaliczyć do typu 3. Pierwszym z takich egzemplarzy jest znalezisko luźne (Bohnsack 1940: 1116) z Boryszyna, pow. Świebodzin $^{12}$ (nr 2, tabl. VIII.1). Innym egzemplarzem ze stosunkowo długą tuleją jest grot z datowanego na fazę C2 grobu (Jahn 1921: 118; Schulz W. 1931: 69-70, Taf. XIV.7; Archiwum...) z Marxdorf, Lkr. Elbe-Elster (nr 14, tabl. VIII.2-3). Niezbyt charakterystyczna forma wymienionych egzemplarzy sprawia, że mogą to być zarówno miejscowe warianty grotów przeworskich, jak i skandynawskich, nie można więc określić na obecnym etapie badań w sposób pewny, z którym z tych dwóch wielkich kręgów należy je łączyć.

Bardzo późnym egzemplarzem jest okaz z grobu 20 z Schönfeld, Lkr. Meißen (Meyer 1971: 195-196, Abb. 113a) (nr 19, tabl. VIII.4). Przypomina on kształtem i proporcjami liścia egzemplarze typu XXII wg P. Kaczanowskiego (1988: 26, tabl. XV.1-2). Jego tuleja jest jednak zbyt długa, by można go było zaliczyć bezwarunkowo do wspomnianego typu.

Ogólna liczba 3 grotów bez skandynawskich cech ale ze stożkowatym przejściem tulei w liść stanowi prawie 3\% wszystkich grotów bez zadziorów w kulturze luboszyckiej. Egzemplarze o cechach północnoeuropejskich z omawianym elementem stanowią prawie 7\% całego zbioru grotów broni drzewcowej bez zadziorów tej jednostki taksonomicznej. Daje to łączny odsetek grotów ze stożkowatym przejściem tulei w liść rzędu 10\% wszystkich egzemplarzy omawianej kategorii uzbrojenia w kulturze luboszyckiej.

Najwięcej egzemplarzy z omawianą cechą można zaobserwować w północnej strefie europejskiego Barbaricum. Wymienić tutaj można stanowiska bagienne w Nydam (Bemmann, Bemmann 1998: 174, 176, 179-180, Taf. 72.702, 76.726, 99.884, 100.885, 100.891, 101.892-896, 102.900) skupisko I (11 sztuk - 5\% całości) i Ejsbøl-Nord (5 sztuk - 2\% całości) (Ørsnes 1988: Taf. 128.1-4, 129.11). Duża grupa (co najmniej 4 sztuki - 18\% całości lub więcej) została znaleziona w depozycie z Vingsted (Ilkjaer 1990: 44, 133, Abb. 103). Ze stanowiska w Illerup pochodzą trzy okazy (nr inw. VHR, AALN i ZNC) noszący omawianą cechę (Ilkjaer 1990: 44, Abb.31, Taf. 26, 140). Ponadto J. Ilkjaer (1990: 44, 363, 387) przytacza dwa groby z terenów skandynawskich zawierających groty tego rodzaju ${ }^{13}$. Biorąc pod uwagę ilość znalezisk elementów broni drzewcowej z depozytów ofiarnych uznać należy frekwencję egzemplarzy ze stożkowatym przejściem tulejki w liść za mało znaczącą.

$\mathrm{Na}$ obszarach środkowoeuropejskiego Barbaricum (oczywiście nie licząc terenu kultury luboszyckiej) okazy o skandynawskich cechach zaopatrzone

\footnotetext{
${ }^{12}$ Archiwum Brandenburgisches Landesamt für Denkmalpflege Wünsdorf.

${ }^{13}$ Pochówki z Jätterör w Szwecji czy Sween w Norwegii.
} 
w stożkowate przejście tulei w liść pojawiają się sporadycznie. Wymienić tutaj można np. grot B ze skarbu z Żarnowca, pow. Puck (Kaczanowski 1988: 227) czy egzemplarz z grobu z 1956 r. z Pečk w Czechach (Motyková-Šnejdrová 1961: 34-35, obr. 25) ${ }^{14}$.

Ciekawie rysuje się sytuacja na obszarze kultury przeworskiej. Choć trudno uznać groty broni drzewcowej bez zadziorów ze stożkowatym przejściem tulei w liść za często spotykane, to jednak tworzą grupę zauważalną ${ }^{15}$ zwłaszcza, że w okresie późnorzymskim ${ }^{16}$ wyraźnie zmniejsza się frekwencja występowania uzbrojenia w pochówkach. Uderzający jest za to fakt, że żaden z grotów ze stożkowatym przejściem tulei w liść nie posiada cech charakterystycznych dla form skandynawskich ${ }^{17}$.

Na obszarze kręgu nadłabskiego w okresie późnorzymskim daje się zauważyć drastyczne zmniejszenie częstotliwości wyposażania pochówków w broń, co utrudnia prowadzenie miarodajnych badań bronioznawczych. Wśród tych grotów broni drzewcowej, które można zaobserwować we wspomnianej jednostce taksonomicznej, egzemplarze ze stożkowatym przejściem tulei w liść są rzadko spotykane $^{18}$.

Trudno odpowiedzieć na pytanie, dlaczego to właśnie w inwentarzu kultury luboszyckiej ta szczególna forma przejścia jest stosunkowo najliczniej reprezentowana. Nie mniejszą zagadką jest jej uderzająca nadreprezentacja wśród egzemplarzy łączonych z kręgiem północnoeuropejskim - gwoli przypomnienia jest to 19 znalezisk, co stanowi ponad 18\% całego zbioru 103 grotów bez zadziorów z terenów kultury luboszyckiej. Jest prawdopodobne, że egzempla-

\footnotetext{
${ }^{14}$ W Muzeum Archeologicznym w Zielonej Górze znajduje się silnie zdeformowany grot ze stożkowatym przejściem tulei w liść, posiadający najprawdopodobniej cechy skandynawskie (nr inw. MZG 544:1958). Ponieważ nie ma żadnych informacji na temat miejsca znalezienia artefaktu, nie wiadomo czy pochodzi on z inwentarza kultury luboszyckiej czy przeworskiej.

${ }^{15}$ Można tutaj wymienić egzemplarze z: Grodziska Mazowieckiego, pow. loco (Barankiewicz 1959: 207, tabl. X.9), grobu 30 z Korzenia, pow. Gostynin (Kempisty 1968: 340-343, tabl. XXIII), obiektów 289 i 493 z Opatowa, pow. Kłobuck (Madyda-Legutko, Rodzińska-Nowak, ZagórskaTelega 2011: 78-79, Taf. XCVII-XCIX, 127-128, Taf. CLXVIII-CLXXI), Poznania-Sołacza (Gałęzowska 1999: 10-11, ryc. 4.4), grobu 152 ze Spicymierza, pow. Turek (Kietlińska, Dąbrowska 1963: 166, tabl. XXI.15-19,23-26), Stryczowic, pow. Ostrowiec Świętokrzyski (Nadolski 1950: 221-223, ryc. 1-2) i Swaryczowa, pow. Zamość (Kokowski, Kuśnierz, Ubański 1997).

${ }^{16}$ Groty ze stożkowatym przejściem tulei w liść spotykane są w kontekstach późnorzymskich. Zwracali na to uwagę już J. Ilkjaer (1990: 44) i J. Bemmannn i G. Bemmannn (1998: 174).

${ }^{17}$ Wyjątkiem mógłby tutaj być grot z grobu 174 ze Spicymierza, pow. Turek (Kietlińska, Dąbrowska 1963: 169, tabl. XXV.1-9), jednak w jego przypadku przejście jest krótkie i tworzy kąt rozwarty, dlatego jego włączenie do omawianej grupy nie wydaje się uprawnione.

${ }^{18}$ Wymienić tutaj należy egzemplarz luźny z Torgau, Lk. Nordsachsen (Schulz 1931: 77, Taf. XIX.18) oraz z grobu 1 z Göttwitz, Lkr. Leipzig (Meyer 1971: 244, Abb. 139).
} 
rze o cechach skandynawskich (przynajmniej część z nich) nie są faktycznymi importami z Północy, a jedynie wytworami miejscowych kowali czerpiących stamtąd wzorce. Przemawiać za tą ewentualnością mógłby fakt, że wiele spośród wymienionych grotów odbiega mniej lub bardziej od ,głównego nurtu” uzbrojenia skandynawskiego (Bemmann 2007: 271-272). Zakładając taką hipotezę, należałoby widzieć w osobliwej formie przejścia tulei w liść element zaczerpnięty najprawdopodobniej ze Skandynawii, który na gruncie kultury luboszyckiej zyskał popularność nieporównywalnie większą niż na terenach macierzystych. Istotną pomoca przy rozstrzygnięciu tego problemu mogą być w przyszłości badania składu chemicznego metalu, z którego te zabytki są wykonane, zwłaszcza w zakresie nietypowych pierwiastków śladowych. Na zakończenie należy stwierdzić, że chronologia grotów o północnoeuropejskich cechach pochodzących z precyzyjnie datowanych zespołów ogranicza się do faz C1b i C2 i to w tym czasie napłynęło na obszar kultury luboszyckiej najwięcej militariów z omawianego kierunku. Niemniej wiele egzemplarzy o szerszej chronologii mogło pochodzić jeszcze z fazy Cla, a dwa znaleziska zaliczane jest do typu używanego aż do fazy C3. Trzeba również zaznaczyć, że pojawienie się grotów broni o cechach skandynawskich nie jest zjawiskiem ograniczonym do terenów kultury luboszyckiej. W tym samym czasie można zauważyć wiele grotów broni drzewcowej ${ }^{19}$, ale też i innych elementów uzbrojenia o północnoeuropejskich konotacjach, na obszarze kręgu nadłabskiego. Analizowane zjawisko jest więc szerszym trendem obejmującym teren dorzecza Łaby, Szprewy i Odry.

mgr Agata Andrzejewska

Uniwersytet Łódzki

Wydział Filozoficzno-Historyczny

Katedra Historii Sztuki

ul. Uniwersytecka 3

90-137 Łódź dr Karol Demkowicz

Uniwersytet Łódzki

Wydział Studiów Międzynarodowych i Politologii

Zakład Studiów Latynoamerykańskich

ul. Składowa $41 / 43$

90-127 Łódź

${ }^{19}$ Berlin-Mariendorf, Glebitzsch, Lkr. Anhalt-Bitterfeld, Gommern, Lkr. Jerichower Land (J. Bemmannn 2007: 256, 254, 271, Abb. 8, 7, 24.1), Lüdersdorf, Lkr. Nordwestmecklemburg (Bohnsack 1940: Taf. 452.7; Leube 1975: 78, Taf. 4.15, 31.7), Verchen, Lkr. MeklemburgischeSeenplatte (Bemmannn 2007: 272, Abb. 27.1). 


\section{KATALOG}

Bautzen, Lkr. Bautzen (okolice)

Znalezisko luźne

1. Grot broni drzewcowej bez zadziorów

Typ: 28 wg J. Ilkjaera

Dł. całk.: $19 \mathrm{~cm}$

Dł. liścia: $13,2 \mathrm{~cm}$

Dł. tulei: $5,8 \mathrm{~cm}$

Szer. liścia: $3 \mathrm{~cm}$

Gr. liścia: $0,7 \mathrm{~cm}$

Śr. tulei: $2,2 \mathrm{~cm}$

Waga: $112 \mathrm{~g}$

Opis: liść przekroju niemal romboidalnego, zaopatrzony w bardzo słabo wyodrębnione żeberko, wierzchołek ułamany. Tuleja o przekroju czworokątnym z zaokrąglonymi bokami, mocno rozszerzająca się ku wylotowi. Tkwi w niej nit mocujący (Tabl. VI.1.)

Chron.: C2-C3 (faza III kult. luboszyckiej)

Miejsce przechowywania: Landesamt für Archäologie Sachsen, nr inw. S.336/56

Lit.: Meyer 1971: 29, Abb. 14.1.

Boryszyn, pow. Świebodzin (niem. Burschen) Znalezisko luźne

2. Grot broni drzewcowej bez zadziorów Typ: 3 wg J. Ilkjaera

Dł. całk.: $17 \mathrm{~cm}$

Dł. liścia: $13,3 \mathrm{~cm}$

Dł. tulei: $3,7 \mathrm{~cm}$

Szer. liścia: $3,5 \mathrm{~cm}$

Gr. liścia: -

Śr. tulei: $2 \mathrm{~cm}$

Waga: -

Opis: liść o przekroju romboidalnym, tuleja o przekroju okragłym, rozszerzająca się ku wylotowi (Tabl. VIII.1.)

Miejsce przechowywania: zabytek zaginiony Chron.: C1-C2 (fazy II-III kult. luboszyckiej) Lit.: Bohnsack 1940: 1116; archiwum Brandenburgisches Landesamt für Denkmalpflege Wünsdorf
Dornswalde, Lkr. Teltow-Fläming
Grób ciałopalny jamowy

3. Grot broni drzewcowej bez zadziorów

Typ: 15 wg J. Ilkjaera

Dł. całk.: $23 \mathrm{~cm}$

Dł. liścia: $17,4 \mathrm{~cm}$

Dł. tulei: $5,6 \mathrm{~cm}$

Szer. liścia: $3,9 \mathrm{~cm}$

Gr. liścia: -

Śr. tulei: $1,9 \mathrm{~cm}$

Waga: -

Opis: liść zaopatrzony w wąskie, precyzyjnie wykute żeberko, tuleja o przekroju ośmiokątnym, lekko rozszerzająca się ku wylotowi (Tabl. IV.1.)

Miejsce przechowywania: Brandenburgisches Landesamt für Denkmalpflege Wünsdorf

Pozostały inwentarz: sprzączka typu D11 i G3 wg R. Madydy-Legutko, fragmenty zapinki lub zapinek A162, okucie końca pasa typu J wg K. Raddatza, dwa noże, krzesiwo sztabkowate, grzebień trójwarstwowy.

Chron.: C1 (faza II kult. luboszyckiej).

Lit.: Brather 2001.

Dziwiszowa, pow. Żagań (niem. Bergisdorf) Znalezisko luźne

4. Grot broni drzewcowej bez zadziorów

Typ: 7 wg J. Ilkjaera

Dł. całk.: $25 \mathrm{~cm}$

Dł. liścia: $16,7 \mathrm{~cm}$

D1. tulei: $8,3 \mathrm{~cm}$

Szer. liścia: $4 \mathrm{~cm}$

Gr. liścia: -

Śr. tulei: $2,5 \mathrm{~cm}$

Waga: -

Opis: liść o przekroju sześciokątnym, tuleja o przekroju czworokątnym o zaokragglonych bokach, lekko rozszerzająca się ku wylotowi. Soczewkowate otwory na nit (Tabl. III.1.)

Chron.: C1 (faza II kult. luboszyckiej)

Miejsce przechowywania: zabytek zaginiony.

Lit.: Tackenberg 1925: 55; archiwum Museum für Vor- und Frühgeschichte Berlin, nr inw. Ie 1199; Archiwum... 
Falkenberg, Lkr. Märkisch-Oderland

Grób ciałopalny jamowy

5. Grot broni drzewcowej bez zadziorów

Typ: 9 wg J. Ilkjaera

Dł. całk.: $24 \mathrm{~cm}$

Dł. liścia: $15,3 \mathrm{~cm}$

Dł. tulei: $8,7 \mathrm{~cm}$

Szer. liścia: $3,4 \mathrm{~cm}$

Gr. liścia: -

Śr. tulei: $2,1 \mathrm{~cm}$

Waga: -

Opis: - . (Tabl. VII.2.)

Miejsce przechowywania: zabytek zaginiony

6. Grot broni drzewcowej z zadziorami

Typ: 3 wg J. Ilkjaera

Dł. całk.: $44,5 \mathrm{~cm}$

Dł. liścia: $6,9 \mathrm{~cm}$

Dł. tulei: $37,6 \mathrm{~cm}$ (zach.)

Szer. liścia: $2,6 \mathrm{~cm}$

Gr. liścia: -

Dł. I zadzioru: -

Dł. II zadzioru: -

Śr. tulei: -

Waga: -

Opis: - . (Tabl. VII.1.)

Miejsce przechowywania: zabytek zaginiony

Pozostały inwentarz: umbo typu $\mathrm{O}$ wg N. Zielinga, gwóźdź z płaską główką (prawd. nit mocujący), fragment sprzączki żelaznej, zagięty drut żelazny, trzy stopione kawałki brązu, dwa naczynia misowate, małe naczynie wazowate

Chron.: C2 (faza III kult. luboszyckiej)

Lit.: Pescheck 1939: 14-16, Abb.1; Leube 1975: 82

Grabice, pow. Krosno Odrzańskie (niem. Reichersdorf)

Tzw. grób 1

Przemieszany pochówek ciałopalny jamowy

7. Grot broni drzewcowej bez zadziorów

Typ: 14 wg J. Ilkjaera

Dł. całk.: $15 \mathrm{~cm}$

Dł. liścia: $10,5 \mathrm{~cm}$

D1. tulei: $4,5 \mathrm{~cm}$

Szer. liścia: $2,5 \mathrm{~cm}$

Gr. liścia: -

Śr. tulei: -
Waga: -

Opis: liść wąski, masywny, najprawdopodobniej zaopatrzony w żeberko. Tuleja rozszerza się ku wylotowi (Tabl. IV.3.)

Chron.: C1b-C2 (fazy II-III kult. luboszyckiej).

Miejsce przechowywania:-

Lit.: Jentsch 1889: 346, Fig. 5; 1895: 111, Fig. 47; archiwum Römisch-Germanisches Zentralmuseum Mainz; niepublikowane materiały prof. G. Domańskiego

\section{Hartmannsdorf, Lkr. Dahme-Spreewald}

Znalezisko luźne

8. Grot broni drzewcowej bez zadziorów

Typ: 15 wg J. Ilkjaera

Dł. całk.: $30,5 \mathrm{~cm}$

Dł. liścia: $24,5 \mathrm{~cm}$

Dł. tulei: $6 \mathrm{~cm}$

Szer. liścia: $5 \mathrm{~cm}$

Gr. liścia: -

Śr. tulei: $2,2 \mathrm{~cm}$

Waga: -

Opis: liść zaopatrzony w precyzyjnie wyodrębnione żeberko. Tuleja o przekroju czworokątnym z zaokraglonymi bokami, mocno rozszerzająca się ku wylotowi. Otwory na nit mocujący kształtu soczewkowatego (Tabl. IV.2.)

Chron.: C1 (faza II kult. luboszyckiej)

Miejsce przechowywania: zabytek zaginiony

Lit.: Jahn 1925: 190, 193, Abb. 1.1.

Horno, Lkr. Spree-Neiße

Cmentarzysko ciałopalne $\mathrm{z}$ konstrukcjami kurhanowymi

Groby wyeksplorowane w czasie badań prowadzonych w $2000 \mathrm{r}$.

Obiekt $4 \mathrm{a}$

Grób popielnicowy

9. Grot broni drzewcowej bez zadziorów

Typ: 4 wg J. Ilkjaera

Dł. całk.: $22,2 \mathrm{~cm}$

D1. liścia: $17,4 \mathrm{~cm}$

Dł. tulei: $4,8 \mathrm{~cm}$

Szer. liścia: $3,5 \mathrm{~cm}$

Gr. liścia: -

Śr. tulei: $2 \mathrm{~cm}$

Waga:- 
Opis: tuleja okrągła, lekko rozszerzająca się $\mathrm{ku}$ wylotowi. Liść przekroju romboidalnego z wgiętą linią ostrzy (Tabl. I.1.)

Miejsce przechowywania: Archäologisches Landesmuseum Brandenburg

Pozostały inwentarz: topór $\mathrm{z}$ symetrycznym ostrzem i wyodrębnionym młotkiem, grzebień trójwarstwowy, nóż, liczne fragmenty żelazne, krzesiwo sztabkowate, pilnik, uchwyt wiaderka, nożyce, 2 duże gwoździe, krzesiwo iglicowe z fragmentem kościanego uchwytu, brązowa sprzączka dwudzielna D-kształtna typu D29 wg R. Madydy-Legutko, brązowe okucie końca pasa typu $\mathrm{O} 15$ wg K. Raddatza, ręcznie lepione naczynie misowate jako popielnica, mały puchar toczony na kole

Chron.: C1b-C2 (fazy II-III kult. luboszykkiej)

Lit.: Schwarzländer 2006: 75-76, Abb. 9-11

Obiekt 4b

Grób ciałopalny jamowy

10. Grot broni drzewcowej bez zadziorów

Typ: 4 wg J. Ilkjaera

Dł. całk.: $15 \mathrm{~cm}$

Dł. liścia: $9,3 \mathrm{~cm}$

Dł. tulei: $5,7 \mathrm{~cm}$

Szer. liścia: $2,2 \mathrm{~cm}$

Gr. liścia: -

Śr. tulei: $1,8 \mathrm{~cm}$

Waga: -

Opis: liść o przekroju romboidalnym, tuleja o przekroju okragłym, rozszerzająca się ku wylotowi. Przejście tulei $\mathrm{w}$ liść o formie stożkowatej (Tabl. I.2.)

Miejsce przechowywania: Archäologisches Landesmuseum Brandenburg

Pozostały inwentarz: miecz typu FolkeslundaZaspy wg M. Biborskiego, żelazna zawieszka pochwy miecza typu IIID1 wg C. von CarnapBornheima, umbo typu $\mathrm{P}$ wg N. Zielinga, imacz typu pośredniego między $\mathrm{V} 1$ a $\mathrm{W}$ wg N. Zielinga, grzebień trójwarstwowy, nóż, uchwyt wiaderka, nożyce, szpila żelazna

Chron.: C1b (faza II kult. luboszyckiej)

Lit.:Schwarzländer 2006: 76-77, Abb. 11-13
Jessern, Lkr. Dahme-Spreewald

Grób ciałopalny jamowy

11. Grot broni drzewcowej bez zadziorów

Typ: 14 wg J. Ilkjaera

Dł. całk.: $20,3 \mathrm{~cm}$

Dł. liścia: $12,9 \mathrm{~cm}$

Dł. tulei: $7,4 \mathrm{~cm}$

Szer. liścia: $2,7 \mathrm{~cm}$

Gr. liścia: -

Śr. tulei: $2 \mathrm{~cm}$

Waga: -

Opis: liść zaopatrzony w słabo wyodrębnione żeberko, taliowany. Wierzchołek najprawdopodobniej ułamany i wtórnie zaostrzony. Tuleja o przekroju czworokątnym z zaokraglonymi bokami, rozszerzająca się ku wylotowi (Tabl. V.1.)

Miejsce przechowywania: Stadtmuseum Cottbus

Pozostały inwentarz: miecz typu FolkeslundaZaspy wg M. Biborskiego, topór z trójkątnymi wąsami, żelazna zawieszka pochwy miecza typu IIID1 wg C. von Carnap-Bornheima, U-kształtny brązowy trzewik pochwy miecza, nóż, nożyce, fragment noża, okucia wiaderka, prostokątne żelazne okucie z tkwiącymi w nich gwoździami, dwa fragmenty żelazne, fragment sprzączki, gliniana misa, fragment glinianego naczynia $\mathrm{z}$ ornamentem radełkowym

Chron.: Clb (faza II kult. luboszyckiej)

Lit.: Geisler 1970: 133-138, Abb. 1-15; Leube 1975: 123, Taf. 28

Kosilenzien, Lkr. Elbe-Elster

Znalezisko luźne

12. Grot broni drzewcowej bez zadziorów

Typ: 4 wg J. Ilkjaera

Dł. całk.: $19,7 \mathrm{~cm}$

Dł. liścia: $13,2 \mathrm{~cm}$

Dł. tulei: $6,5 \mathrm{~cm}$

Szer. liścia: $2,8 \mathrm{~cm}$

Gr. liścia: $0,7 \mathrm{~cm}$

Sr. tulei: $2,1 \mathrm{~cm}$

Waga: -

Opis: liść przekroju romboidalnego, z taliowanymi brzegami. Tuleja okragła w przekroju, zwężająca się ku wylotowi. Przejście tulei w liść stożkowate (Rycina: I.3.)

Chron.: C1-C2 (fazy II-III kult. luboszyckiej) 
Miejsce przechowywania: Museum für Vorund Frühgeschichte Berlin, nr inw. Ig 3495

Lit.: Gandert 1929: 174; Schulz W. 1931: 62; Domański 1979: 238; Archiwum...

Kranichau, Lkr. Nordsachsen

Znalezisko luźne

13. Grot broni drzewcowej bez zadziorów

Typ: 28 wg J. Ilkjaera

Dł. całk.: $21 \mathrm{~cm}$

Dł. liścia: $15 \mathrm{~cm}$

Dł. tulei: $6 \mathrm{~cm}$

Szer. liścia: $3,4 \mathrm{~cm}$

Gr. liścia: -

Śr. tulei: $2,2 \mathrm{~cm}$

Waga: -

Opis: liść o przekroju romboidalnym, tuleja o przekroju okrąłym, rozszerzająca się ku wylotowi (Tabl. VI.2.)

Miejsce przechowywania: zabytek zaginiony

Chron.: C2-C3 (faza III kult. luboszyckiej)

Lit.: Schulz W. 1931: 75, Taf. XVIII.3; Meyer 1971: 260, Abb. 147.1

Marxdorf, Lkr. Märkisch-Oderland

Grób ciałopalny popielnicowy (?)

14. Grot broni drzewcowej bez zadziorów

Typ: 3 wg J. Ilkjaera

Dł. całk.: $12 \mathrm{~cm}$

Dł. liścia: $7,4 \mathrm{~cm}$

Dł. tulei: $4,6 \mathrm{~cm}$

Szer. liścia: $2 \mathrm{~cm}$

Gr. liścia: $1 \mathrm{~cm}$

Śr. tulei: $1,5 \mathrm{~cm}$

Waga: -

Opis: liść o przekroju romboidalnym, tuleja o przekroju okrąłym, lekko rozszerzająca się ku wylotowi. Stożkowate przejście tulei w liść (Tabl. VIII.2-3.)

Miejsce przechowywania: zabytek zaginiony

Pozostały inwentarz: miecz, para ostóg kabłąkowych z poprzeczkowatymi zaczepami, okucia wiaderka, sprzączka B8 wg R. Madydy-

Legutko, waza toczona na kole

Chron.: C2 (faza III kult. luboszyckiej)

Lit.: Jahn 1921: 118; Gandert 1929:172, Abb. 52.c-e; Schulz W. 1931: 69, Taf. XIV; Archiwum...
Niewitz, Lkr. Dahme-Spreewald

Grób 1

Ciałopalny popielnicowy ze zsypanym stosem

15. Grot broni drzewcowej bez zadziorów

Typ: 17 wg J. Ilkjaera

Dł. całk.: $23 \mathrm{~cm}$

Dł. liścia: $14,5 \mathrm{~cm}$

Dł. tulei: $8,5 \mathrm{~cm}$

Szer. liścia: 3,5 cm (zach.)

Gr. liścia: -

Śr. tulei: -

Waga: -

Opis: liść zaopatrzony w wyodrębnione i precyzyjnie wykute żeberko, wchodzące głęboko na tuleję (Tabl. III.4.)

Miejsce przechowywania: Stadtmuseum Cottbus.

Pozostały inwentarz: topór $\mathrm{z}$ trójkątnymi wąsami, naczynie gliniane, nożyce, okucia wiaderka

Chron.: C1b (faza II kult. luboszyckiej)

Lit.: Jentsch 1895: 126; Marschalleck 1944: 139, Abb. 46; Leube 1975: 124, Taf. 27.1-2; Archiwum...

Prieschka, Lkr. Elbe-Elster

Zniszczone cmentarzysko ciałopalne

16. Grot broni drzewcowej bez zadziorów

Typ: 4 wg J. Ilkjaera

Dł. całk.: $22,2 \mathrm{~cm}$

Dł. liścia: $16,2 \mathrm{~cm}$

Dł. tulei: $6 \mathrm{~cm}$

Szer. liścia: $3,7 \mathrm{~cm}$

Gr. liścia: $0,8 \mathrm{~cm}$

Śr. tulei: $2 \mathrm{~cm}$

Waga: $189 \mathrm{~g}$

Opis: liść o przekroju romboidalnym, tuleja o przekroju czworokątnym z zaokrąglonymi bokami. Przejście tulei w liść ma postać zbliżoną do ostrosłupa (Tabl. II.1.)

Miejsce przechowywania: Museum für Vorund Frühgeschichte Berlin, nr inw. Ig 3925b

Chron.: C1-C2 (fazy II-III kult. luboszyckiej)

Lit.: Gandert 1929: 174; Archiwum...

17. Grot broni drzewcowej bez zadziorów

Typ: 4 wg J. Ilkjaera

Dł. całk.: $15,5 \mathrm{~cm}$

Dł. liścia: $10,3 \mathrm{~cm}$ 
Dł. tulei: $5,2 \mathrm{~cm}$

Szer. liścia: $3,6 \mathrm{~cm}$

Gr. liścia: $0,9 \mathrm{~cm}$

Śr. tulei: $2,2 \mathrm{~cm}$

Waga: $137 \mathrm{~g}$

Opis: liść o przekroju romboidalnym, tuleja

o przekroju czworokątnym z zaokrąglonymi

bokami. Przejście tulei w liść ma postać zbliżoną do ostrosłupa - pierwotnie pokryty był ornamentem równoległych kresek. Liść o zarysie asymetrycznym (Tabl. II.2.)

Miejsce przechowywania: Museum für Vorund Frühgeschichte Berlin, nr inw. Ig 3925c

Chron.: C1-C2 (fazy II-III kult. luboszyckiej) Lit.: Gandert 1929: 174; Archiwum...

18. Grot broni drzewcowej z zadziorami Typ: 3 wg J. Ilkjaera

Dł. całk.: $24,6 \mathrm{~cm}$

Dł. liścia: $4,7 \mathrm{~cm}$

Dł. tulei: $19,9 \mathrm{~cm}$

Szer. liścia: $2,6 \mathrm{~cm}$

Gr. liścia: $0,4 \mathrm{~cm}$

Dł. I zadzioru: $2,2 \mathrm{~cm}$

Dł. II zadzioru:-

Śr. tulei: $2 \mathrm{~cm}$

Waga: $71 \mathrm{~g}$

Opis: tuleja dwunastokatna, jeden zadzior odłamany (Tabl. VIII.3.)

Miejsce przechowywania: Museum für Vorund Frühgeschichte Berlin, nr inw. Ig 3925e Chron.: C2 (faza III kult. luboszyckiej)

Lit.: Gandert 1929: 174; Bemmann J. 2007, 272, Abb. 27.5; Archiwum...

Schönfeld, Lkr. Meißen

Grób 20

Ciałopalny jamowy (?)

19. Grot broni drzewcowej bez zadziorów Typ: niemieszczący się w klasyfikacji

P. Kaczanowskiego

Dł. całk.: $19,2 \mathrm{~cm}$

Dł. liścia: $11,8 \mathrm{~cm}$

Dł. tulei: $7,5 \mathrm{~cm}$

Szer. liścia: $2,3 \mathrm{~cm}$

Gr. liścia: $0,9 \mathrm{~cm}$

Śr. tulei: $2,1 \mathrm{~cm}$

Waga: $141 \mathrm{~g}$
Opis: liść o przekroju romboidalnym, tuleja o przekroju okragłym, lekko rozszerzająca się ku wylotowi. Przejście tulei w liść stożkowate (Tabl. VIII.4.)

Miejsce przechowywania: Landesamt für Archäologie Sachsen, nr inw. S.724/70

Pozostały inwentarz: brązowa sprzączka o owalnej ramie ze zwierzęcymi główkami typu I1 wg R. Madydy-Legutko

Chron.: C3 (faza III kult. luboszyckiej)

Lit.: Meyer 1971: 195-196, Abb. 113.a-b

Stolzenhain, Lkr. Elbe-Elster

Znaleziska luźne ze zniszczonego cmentarzyska Tzw. grób 1. Przemieszany grób ciałopalny

20. Grot broni drzewcowej bez zadziorów

Typ: 14 wg J. Ilkjaera

Dł. całk.: $21 \mathrm{~cm}$

Dł. liścia: $13,7 \mathrm{~cm}$

Dł. tulei: $7,3 \mathrm{~cm}$

Szer. liścia: $3,3 \mathrm{~cm}$

Gr. liścia: -

Śr. tulei: $2 \mathrm{~cm}$

Waga: -

Opis: liść zaopatrzony w żeberko biegnące przez całą długość tego elementu, tuleja o przekroju czworokatnym o zaokrąglonych bokach, rozszerzajaca się ku wylotowi (Tabl. V.2.)

Miejsce przechowywania: zabytek zaginiony Chron.: C1b-C2 (fazy II-III kult. luboszyckiej)

Lit.: Schulz W. 1931: 64, Taf. XI.3, XIII.1.

21. Grot broni drzewcowej bez zadziorów Typ: $14 \mathrm{wg}$ J. Ilkjaera

Dł. całk.: $17 \mathrm{~cm}$

D1. liścia: $10,7 \mathrm{~cm}$

D1. tulei: $6,3 \mathrm{~cm}$

Szer. liścia: $2,8 \mathrm{~cm}$

Gr. liścia: -

Śr. tulei: $2,3 \mathrm{~cm}$

Waga: -

Opis: liść zaopatrzony w żeberko biegnące przez całą długość tego elementu, rozszerzająca się ku wylotowi. Zabytek mocno skorodowany i najprawdopodobniej uszkodzony (Tabl. V.3.) Miejsce przechowywania: zabytek zaginiony Chron.: C1b-C2 (fazy II-III kult. luboszyckiej) Lit.: Schulz W. 1931: 64, Taf. XI.10 
22. Grot broni drzewcowej z zadziorami Typ: 8 wg J. Ilkjaera

Dł. całk.: $21,7 \mathrm{~cm}$

Dł. liścia: $9,5 \mathrm{~cm}$

Dł. tulei: $12,2 \mathrm{~cm}$

Szer. liścia (na wysokości końca tulei): $2,9 \mathrm{~cm}$

Rozstaw wierzchołków zadziorów: $3,6 \mathrm{~cm}$

Gr. liścia: -

Dł. I zadzioru: $4,4 \mathrm{~cm}$

Dł. II zadzioru: $4,9 \mathrm{~cm}$

Śr. tulei: $1,6 \mathrm{~cm}$

Waga: -

Opis: tuleja o przekroju ośmiokątnym w górnym odcinku, ilość boków zwiększa się w dolnym odcinku (Tabl. VI.3.)

Miejsce przechowywania: zabytek zaginiony

Chron.: C1 (faza II kult. luboszyckiej)

Lit.: Schulz W. 1931: 64, Taf. XI.1

Tzw. grób 3

Przemieszany grób ciałopalny

23. Grot broni drzewcowej bez zadziorów

Typ: 10 wg J. Ilkjaera

Dł. całk.: $19 \mathrm{~cm}$

Dł. liścia: $13,6 \mathrm{~cm}$

Dł. tulei: $5,4 \mathrm{~cm}$

Szer. liścia: $3,2 \mathrm{~cm}$

Gr. liścia: -

Śr. tulei: $1,9 \mathrm{~cm}$

Waga: -

Opis: liść zaopatrzony w żeberko biegnące do ok. połowy długości tego elementu, z wyraźnym wgięciem linii krawędzi. Tuleja rozszerzająca się ku wylotowi (Tabl. III.3.)

Miejsce przechowywania: zabytek zaginiony

Chron.: C1 (faza II kult. luboszyckiej)

Lit.: Schulz W. 1931: 67, Taf. XII.1.

$\underline{\text { Straupitz Lkr. Dahme-Spreewald }}$

Znalezisko luźne

24. Grot broni drzewcowej bez zadziorów

Typ: 10 wg J. Ilkjaera

Dł. całk.: $25,2 \mathrm{~cm}$

Dł. liścia: $20,5 \mathrm{~cm}$

Dł. tulei: $4,7 \mathrm{~cm}$

Szer. liścia: $4 \mathrm{~cm}$

Gr. liścia: $0,5 \mathrm{~cm}$

Śr. tulei: $2 \mathrm{~cm}$

Waga: $170 \mathrm{~g}$
Opis: liść zaopatrzony w żeberko sięgające za jego połowę. Tuleja dwunastoboczna w przekroju, lekko rozszerzająca się ku wylotowi. Liść zaopatrzony w ornament ograniczony półkolistymi polami ułożonymi symetrycznie po obydwu stronach żeberka (Tabl. III.2.)

Chron.: C1 (faza II kult. luboszyckiej)

Miejsce przechowywania: Stadtmuseum Cottbus

Lit.: Weineck 1896: 321-350; Bohnsack 1940: 1087-1088, Taf. 449.5, 450.2; Leube 1975: 125

\section{Ullersdorf, Lkr. Görlitz \\ Znalezisko luźne}

25. Grot broni drzewcowej bez zadziorów

Typ: 14 wg J. Ilkjaera

Dł. całk.: $23,7 \mathrm{~cm}$

Dł. liścia: $17,3 \mathrm{~cm}$

Dł. tulei: $6,4 \mathrm{~cm}$

Szer. liścia: $2,3 \mathrm{~cm}$

Gr. liścia: $0,8 \mathrm{~cm}$

Śr. tulei: $1,8 \mathrm{~cm}$

Waga: $112 \mathrm{~g}$

Opis: liść zaopatrzony w wydatne żeberko. Tuleja ośmiokątna, rozszerzająca się ku wylotowi (Tabl. V.4.)

Chron.: C2 (faza III kult. luboszyckiej)

Miejsce przechowywania: Kulturhistorisches Museum Görlitz

Lit.: Schultz H. A. 1937: 30-31, Abb. 9; Meyer 1971: 205, Abb. 120.1 


\section{Bibliografia}

Źródła

Archiwum.., Archiwum M. Jahna, Instytut Archeologii Uniwersytetu Warszawskiego.

Opracowania

Barankiewicz B. (1959), Cmentarzysko z okresu rzymskiego w Grodzisku Mazowieckim, „Materiały Starożytne”, t. 5, s. 191-232.

Bemmann J. (2007), Anmerkungen zu Waffenbeigabensitte und Waffenformen während der jüngeren Römischen Kaiserzeit und der Völkerwanderungszeit in Mitteldeutschland, ,Alt-Thüringen”, t. 40, s. 247-290.

Bemmann G., Bemmann J. (1998), Der Opferplatz von Nydam. Die Funde aus den älteren Grabungen: Nydam-I und Nydam-II, Band 1: Tekst, Band 2: Katalog und Tafeln, Wachholtz Verlag, Neumunster.

Bemmann J., Hahne G. (1994), Waffenführende Grabinventare der jüngeren römischen Kaiserzeit un Völkerwanderungszeit in Skandinavien. Studie zur zeitlichen Odnung anhand der norwegischen Funde, „Bericht der Römisch-Germanische Kommission", t. 75, s. 283-640.

Biborski M. Ilkjaer J. 2006, Illerup Ådal. Die Schwerter. Textband, „Jutland Archeological Society Publications", t. 25.11, Aarhus.

Bohnsack D. (1940), Die Burgunden, [w:] Vorgeschichte der deutschen Stämme, red. H. Reinerth, t. 3, Leipzig Bibliographisches Institut, Berlin, s. 1033-1148.

Brather M. J. (2001), In voller Montur. Kriegergrab der jüngeren Kaiserzeit aus Dornswalde, Landkreis Teltow-Fläming, „Archäologie in Berlin und Brandenburg", t. 10, s. 89-93.

Carnap-Bornheim C. v. (1991), Die Schwertriemenbügel aus dem Vimose (Fünen), „Kleine Schriften aus dem vorgeschichtlichen Seminar aus dem PhillipsUniversität Marburg", t. 38, Marburg.

Domański G. (1979), Kultura luboszycka między Łabqa Odra wII-IV wieku, Ossolineum, Wrocław.

Domański G. (2008), Ceramika kultury luboszyckiej wykonana na kole garncarskim, [w:] Ceramika warsztatowa w środkowoeuropejskim Barbaricum, red. A. Błażejewski, Instytut Archeologii Uniwersytetu Wrocławskiego, Wrocław, s. $145-163$.

Domański G. (2010a), Dorzecze dolnej Nysy Łużyckiej u schyłku starożytności, Wydawnictwo Instytutu Archeologii i Etnologii PAN Oddział we Wrocławiu, Wrocław.

Domański G. (2010b), Zróżnicowanie obrzqdku pogrzebowego kultury luboszyckiej, [w:] Terra Barbarica. Studia ofiarowane Magdalenie Maczyńskiej w 65. Rocznice urodzin, red. A. Urbaniak, R. Prochowicz, I. Jakubczyk, M. Levada, J. Schuster, Monumenta Archaeologica Barbarica, Series Gemina, t. II, 
Instytut Archeologii Uniwersytetu Łódzkiego, Fundacja MAB, ŁódźWarszawa, s. 239-250.

Gandert O. F. (1929), Die späte Kaiserzeit, [w:] Heimatkunde für den Kreis Liebenwerda, hrsg. O. Bornschein, O. F. Gandert, Verlag C. Ziehlke, Liebenwerda, s. $172-175$.

Gałęzowska A. (1999), Sołacz w okresie wpływów rzymskich. Odkrycia archeologiczne z końca XIX i poczqtku XX wieku, „Kronika Miasta Poznania”, t. 3, s. 7-26.

Geisler H. (1970), Zwei spätgermanische Brandgräber aus dem Bezirk Cottbus, „Niederlausitzer Studien”, t. 4, s. 133-141.

Godłowski K. (1988) Problemy chronologii okresu rzymskiego, [w:] Scripta Archaeologica, red. M. Gedl, Varia, t. 231, Uniwersytet Jagielloński, PWN, Warszawa-Kraków, s. 27-49.

Ilkjaer J. (1990), Illerup Adal. Die Lanzen und Speere, „Jutland Archeological Society Publications", t. 25.1-2, Aarhus.

Ilkjaer J., Biborski M. (2006), Illerup Ådal. Die Schwerter. Textband, „Jutland Archeological Society Publications", t. 25.11, Aarhus.

Jahn M. (1921), Der Reitersporn. Seine Entstehung und früheste Entwicklung, Mannus-Bibl. 21, Leipzig.

Jahn M. (1925), Neue spätkaiserzeitliche Funde aus der Lausitz, [w:] Studien zu vorgeschichtlichen Archäologie. Alfred Götze zu seinem 60. Geburtstage dargebracht von Kollegen, Freuden und Schülern in deren Aufgang, Hrsg. H. Mötefindt, C. Kobitzsch, Leipzig, s. 190-198.

Jentsch H. (1889), Gräberfunde aus der Zeit des späteren provinzialrömischen Einflüssen bei Reichersdorf, Kr. Guben, ,Zeitschrift für Ethnologie”, t. 21, s. 343-352.

Jentsch H. (1895), Das Gräberfeld bei Sadersdorf, Kr. Guben, und ändere Niederlausitzer Fundstellen der La-Téne und provinzialrömischen Zeit, „Niederlausitzer Mitteilungen", t. 4, s. 1-143.

Kaczanowski P. (1988), Chronologia inkrustowanych grotów broni drzewcowej z okresu wpływów rzymskich z obszaru europejskiego Barbaricum, [w:] Scripta Archaeologica, red. M. Gedl, Varia, t. 231, Uniwersytet Jagielloński, PWN, Warszawa-Kraków, s. 51-77.

Kaczanowski P. (1995), Klasyfikacja grotów broni drzewcowej kultury przeworskiej z okresu rzymskiego, Varia, t. 342, Uniwersytet Jagielloński, Kraków.

Kaczanowski P., Zaborowski J. (1988), Bemerkungen über die Bewaffnung der Bevölkerung der Wielbark-Kultur, [w:] Kultura wielbarska w młodszym okresie rzymskim, red. J. Gurba, A. Kokowski, t. 1, UMCS, Lublin, s. 221-239.

Kempisty A. (1968), Ciałopalne cmentarzysko z późnego okresu rzymskiego w miejscowości Korzeń, pow. Gostynin, „Materiały Starożytne”, t. 11, s. $303-416$. 
Kietlińska A., Dąbrowska T. (1963), Cmentarzysko z okresu rzymskiego we wsi Spicymierz, pow. Turek, „Materiały Starożytne”, s. 143-254.

Kokowski A., Kuśnierz J., Urbański A. (1997), Grób wojownika kultury przeworskiej z miejscowości Swaryczów w woj. zamojskim, [w:] Kultura przeworska, t. 3, red. J. Gurba, A. Kokowski, Wydawnictwo UMCS, Lublin, s. 141-150.

Kontny B. (2008), Dawna technika na nowo odkryta - uwagi na marginesie znaleziska grotu z Łodzi-Łagiewnik, „Silesia Antiqua”, t. 44, s. 135-169.

Kossina G. (1905), Über verzierte Eisenlanzenspitzen als Kennezeichen der Ostgermanen, „Zeitschrift für Ethnologie”, t. 37, s. 369-407.

Leube A. (1975), Die römische Kaiserzeit im Oder-Spree-Gebiet, Veröffentlichungen des Museums für Ur- und Frühgeschichte Potsdam, t. 9, Berlin.

Madyda-Legutko R. (1986), Die Gürtelschnallen der Römischen Kaiserzeit und der frühen Völkerwanderungszeit im mitteleuropäischen Barbaricum, Bulletin of Archeological Research International Series, t. 360, Oxford.

Madyda-Legutko R., Rodzińska-Nowak J., Zagórska-Telega J. (2011) Opatów Fpl. 1. Ein Gräberfeld der Przeworsk-Kultur im nordwestlichen Kleinpolen. Katalog, Monumenta Archaeologica Barbarica, t. 15.1-2, Warszawa-Kraków.

Marschalleck K. H. (1944), Urgeschichte des Kreises Luckau (Niederlausitz), Verlag Brüke, Kirchhain N.-L.

Meyer E. (1971), Die germanischen Bodenfunde der spätrömischen Kaiserzeit und der frühen Völkerwanderungszeit in Sachsen, I. Katalog, „Arbeits- und Forschungsberichte zur sächsische Bodendenkmalpflege", t. 9, Berlin.

Motyková-Šnejdrová K. (1961), Nálezy z doby řmské v Pečkách, „Archeologické rozhledy", t. 13, s. 33-40.

Nadolski A. (1950), Kilka uwag o inkrustowanych grotach oszczepów z późnego okresu rzymskiego, „Slavia Antiqua”, t. 2, s. 220-240.

Ørsnes M. (1988), Ejsbøl I. Waffenopferfunde des 4.-5. Jahrhunderts nach Chr., Nordiske Fortidsminder, serie B, Bd. 11, København.

Pescheck Ch. (1939), Ein Burgundengrab aus Falkenberg, Kr. Lebus in RömischGermanischen Zentralmuseum Mainz, „Mainzener Zeitschrift”, t. 34, s. $14-16$.

Raddatz K. (1957), Der Thorsberger Moorfund. Gürtelteile und Körperschmuck, Wachholtz, Neumünster.

Schulz W. (1931), Ost- und Elbgermanen in spätromischer Zeit in den Ostkreisen der Provinz Sachsen, „Jahresschrift für die Vorgeschichte der sächsischesthüringisches Länder", t. 19, s. 62-95.

Schultz H. A. (1937), Die Burgunden im Gebiete der heutigen Preußischen Oberlausitz, „Jahreshefte der Gesellschaft für Anthropologie, Urgeschichte und Volkskunde der Preußischen Oberlausitz", t. 4. 
Schuster J. (1998), Zur ostbrandenburgisch-ostsächsischen Drehscheibenkeramik, [w:] 20 lat archeologii w Masłomęczu, t. 2, Goście, red. J. Ilkjaer, A. Kokowski, Wydawnictwo UMCS, Lublin, s. 203-214.

Schuster J. (2008), Ceramika toczona na kole między środkowa Odra a Łaba, [w:] Ceramika warsztatowa w środkowoeuropejskim Barbaricum, red. A. Błażejewski, Instytut Archeologii Uniwersytetu Wrocławskiego, Wrocław, s. 131-143.

Schwarzländer S. (2006), Das germanische Hügelgräberfeld in Horno, Fpl. 1, Lkr. Spree-Neise. Ergebnisse einer archäologischen Teiluntersuchung, „Veröffentlichungen zur Brandenburgischen Landesarchäologie”, t. 38, s. $45-82$.

Tackenberg K. (1925), Die Wandalen in Niederschlesien, Vorgeschichtliche Forschungen Bd. 1, Berlin.

Weineck F. (1896), Der straupitzer Eisenfund, „Niederlausitzer Mitteilungen”, t. 4, s. $321-350$.

Zieling N. (1989), Studien zu germanischen Schilden der Spätlatene- und der römischen Kaiserzeit im freien Germanien, Bulletin of Archeological Research International Series, t. 505, Oxford.

\section{Summary}

\section{SHAFTED WEAPONS' HEADS WITH SCANDINAVIAN FEATURES FROM THE LUBOSZYCE CULTURE}

The armament from the Luboszyce culture is a true mix of influences coming either from the West, East or even the North. The contacts with the last of these have already been mentioned in the publications dealing with the cultural processes in the basins of middle Oder and Elbe rivers, however, in none of them was the true intensity of this phenomenon emphasized with proper strength. The purpose of this article is to change this situation by focusing on the category of shafted weapons' heads. Scandinavianlike artifacts of this type from the territory of the Luboszyce culture are dated mostly within the $\mathrm{C} 1 \mathrm{~b}$ and $\mathrm{C} 2$ periods. However, some single loose (and thereby devoid of reliable context) finds that represent the head types of lesser chronological sensitivity might even be positioned as early as the phase C1a, while others as late as phase C3. The overall number of northern type spearheads is 19 from the total of 102 finds of this weapon category from the culture in question, which brings a strong $18 \%$ ratio. As far as javelin heads are concerned ( 3 are known from the discussed territory), all of them show Scandinavian influence. This means that the population of the Luboszyce culture maintained really intense contacts with the North in the very time of the unrests that led to the creation of the Danish bog deposits. 
In the discussed group of artifacts one peculiar feature can be observed. Many of the Scandinavian - like spearheads have a conic (or pyramid) - shaped area of transition between the socket and the leaf. Similar elements can be observed in late roman period spearheads both from the Northern circle and Przeworsk culture, but in either case they are rather infrequent. Within the Luboszyce culture spearheads with the mentioned feature constitute a $10 \%$ of the whole weapon category, while among Scandinavianinfluenced artifacts they fetch a 37\%. This means that conic/pyramid - shaped socket/leaf transition is far more widespread among northern type spearheads from the Luboszyce culture than they are in genuine Scandinavian contexts.

All these peculiarities deserve further, intensive and in-depth studies. Let's hope further excavations and new finds as well as new research (including laboratory methods such as metallographic examination) of the existing artifacts will enable us to understand their significance better. 

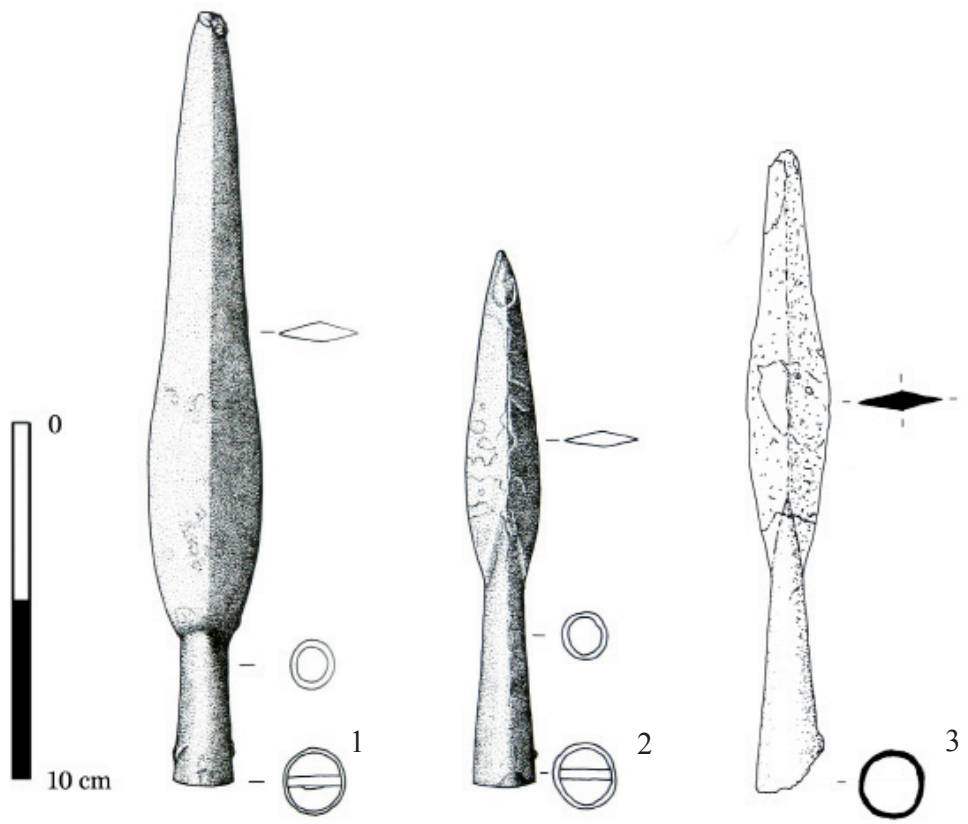

Tabl. I: 1 - Horno, Lkr. Spree-Neiße, obiekt 4a; 2 - Horno, Lkr. Spree-Neiße, obiekt 4b; 3 - Kosilenzien, Lkr. Elbe-Elster

(Źródło: 1, 2 - Schwarzländern 2006: Abb. 10, 11; 3 - rys. A. Andrzejewska)

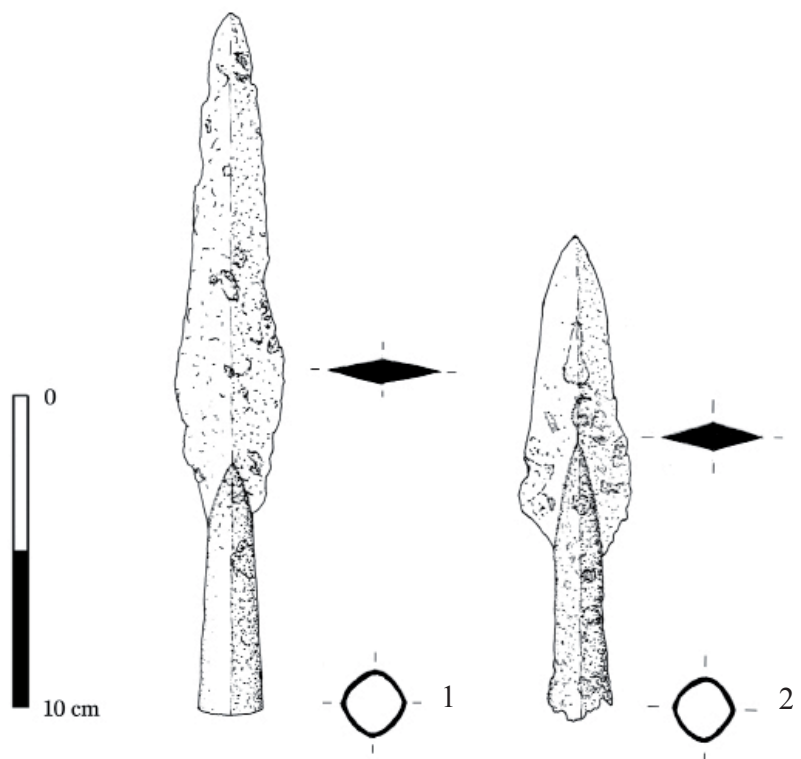

Tabl. II: 1, 2 - Prieschka, Lkr. Elbe-Elster

(Rys. A. Andrzejewska) 

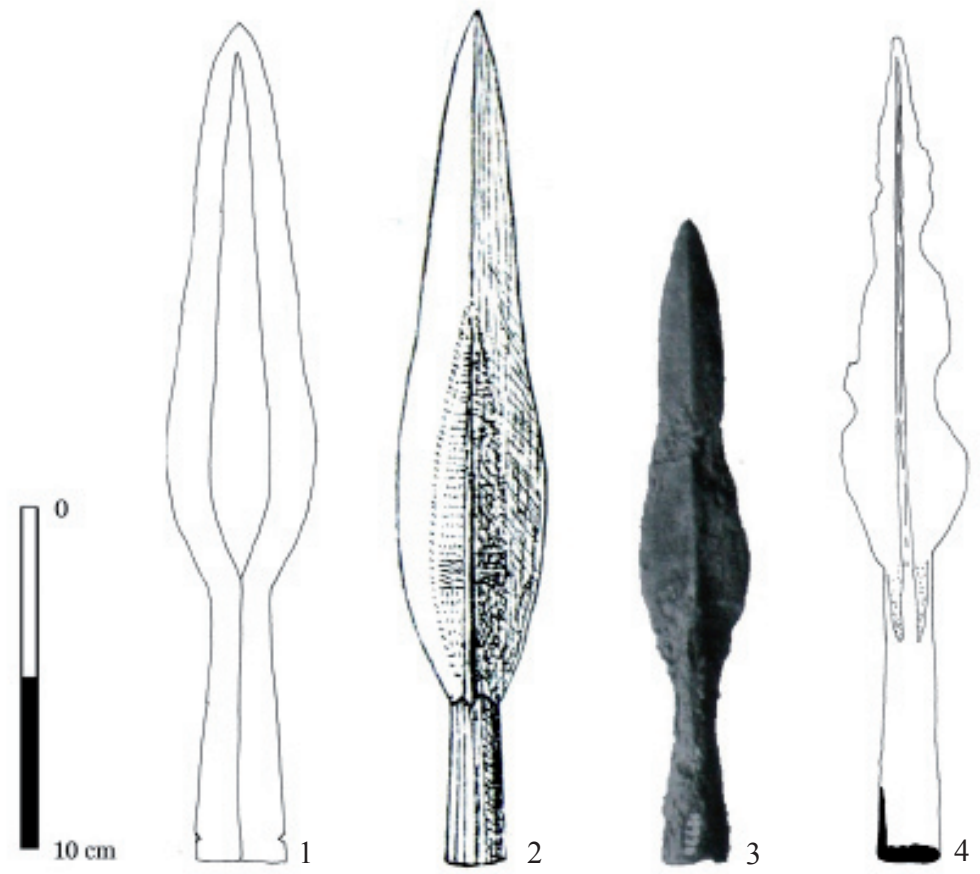

Tabl. III: 1 - Dziwiszowa, pow. Żagań; 2 - Straupitz, Lkr. Dahme-Spreewald; 3 - Stolzenhain, Lkr. Elbe-Elster, tzw. grób 3; 4 - Niewitz, Lkr. Dahme-Spreewald, grób 1 (Źródło: 1, 4-rys. A. Andrzejewska, Archiwum...; 2 - Weineck 1896: Fig. 4; 3 - Schulz W. 1931: Taf. XII.1)

Tabl. IV: 1 - Dornswalde, Lkr. Teltow-Fläming; 2 - Hartmannsdorf, Lkr. Dahme-Spreewald; 3 - Grabice, pow. Krosno Odrzańskie, tzw. grób 1

(Źródło: 1 - Brather 2001: Abb. 69; 2 - Jahn 1925: Abb. 1;

3 - archiwum Römisch-Germanisches Zentralmuseum Mainz, materiały prof. G. Domańskiego)
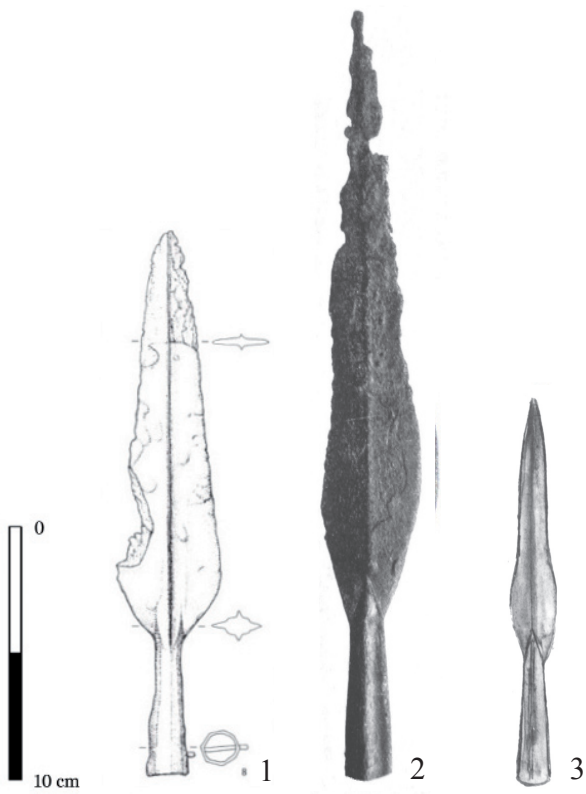

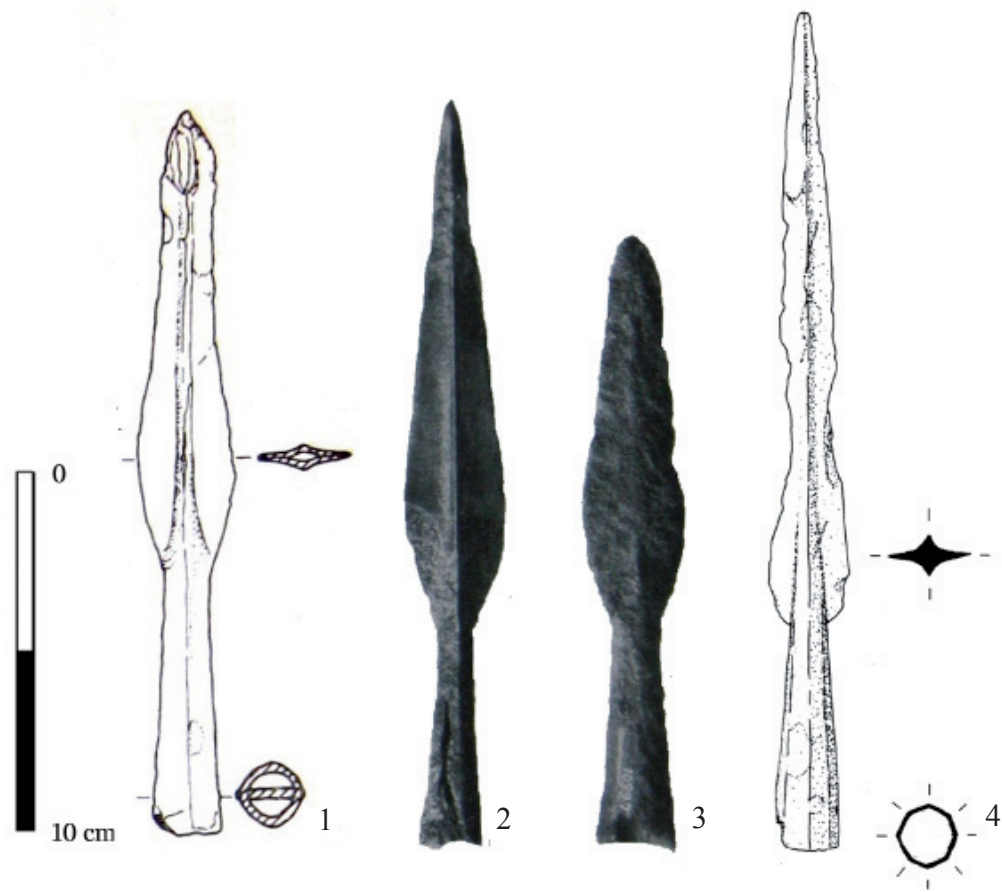

Tabl. V: 1 - Jessern, Lkr. Dahme-Spreewald; 2, 3 - Stolzenhain, Lkr. Elbe-Elster, tzw. grób 1; 4 - Ullersdorf, Lkr. Görlitz

(Źródło: 1 - Geisler 1970: Abb. 8; 2, 3 - Schulz W. 1931: Taf. XI.3, XI.10; 4 - rys. A. Andrzejewska; )
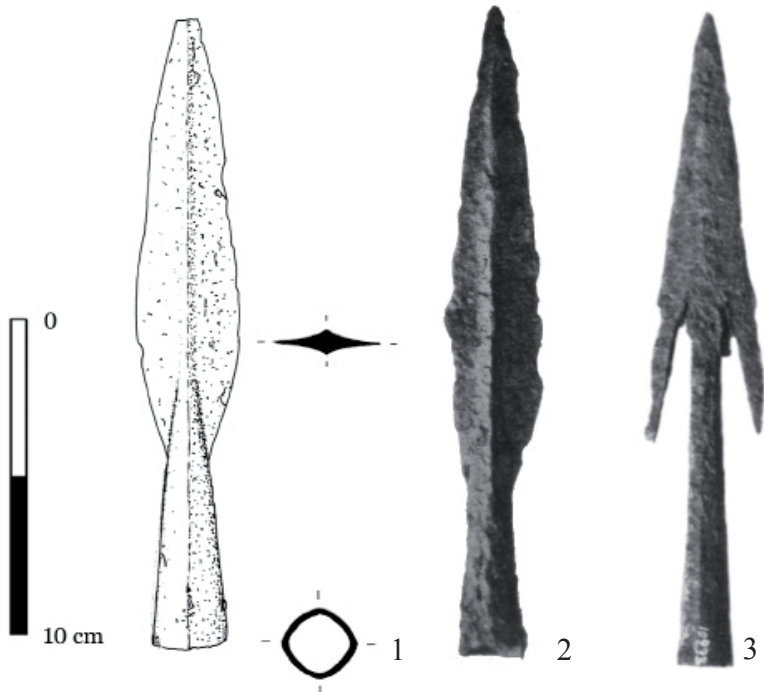

Tabl. VI: 1 - okolice Bautzen, Lkr. Bautzen; 2 - Kranichau, Lkr. Nordsachsen; 3 - Stolzenhain, Lkr. Elbe-Elster, tzw. grób 1

(Źródło: 1 -rys. A. Andrzejewska; 2, 3 - Schulz W. 1931: Taf. XI.1, XVIII.3) 

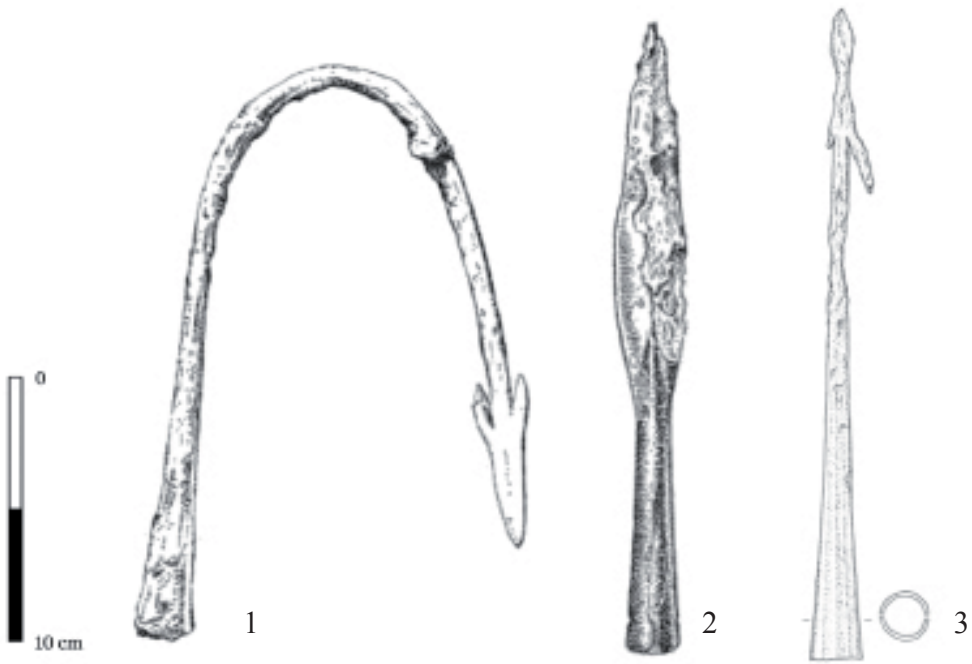

Tabl. VII: 1, 2 - Falkenberg, Lkr. Märkisch-Oderland; 3 - Prieschka, Lkr. Elbe-Elster

(Żródło:1, 2 - Pescheck 1939: Abb. 1; 3 - Bemmann 2007: Abb. 27.5)
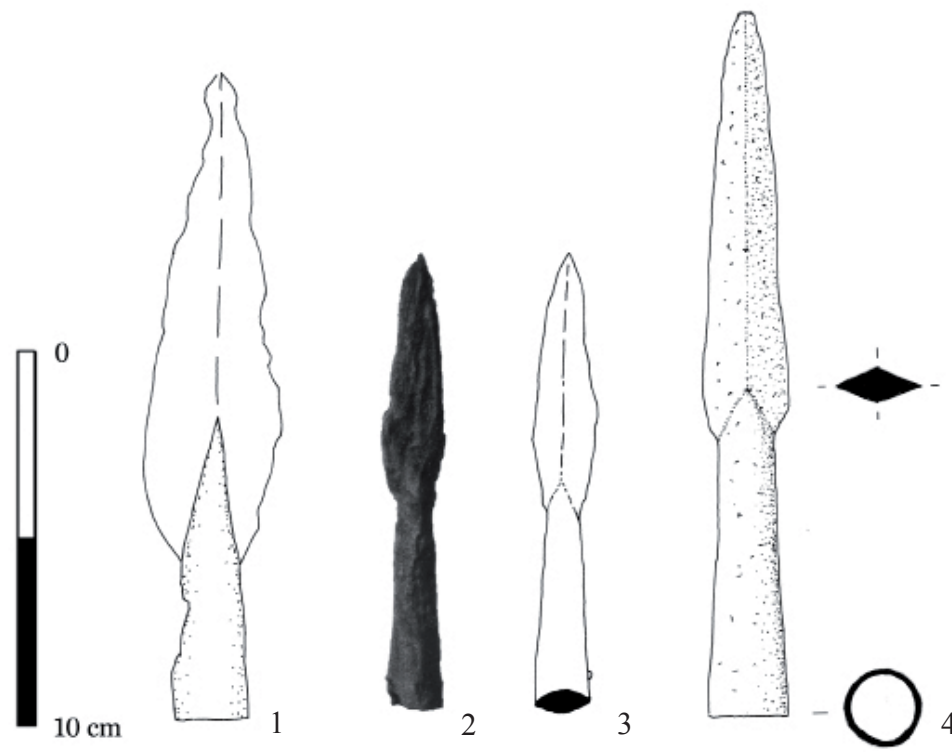

Tabl. VIII: 1 - Boryszyn, pow. Świebodzin; 2, 3 - Marxdorf, Lkr. Elbe-Elster; 4 - Schönfeld, Lkr. Meißen, grób 20

(Źródło: 1 - rys. A. Andrzejewska, materiały archiwum Brandenburgisches Landesamt für Denkmalpflege und Archäologisches Landesmuseum Ortsteil Wünsdorf;

2 - Schulz W. 1931: Taf. XIV.7; 3 - rys. A. Andrzejewska, Archiwum...; 4 - rys. A. Andrzejewska) 

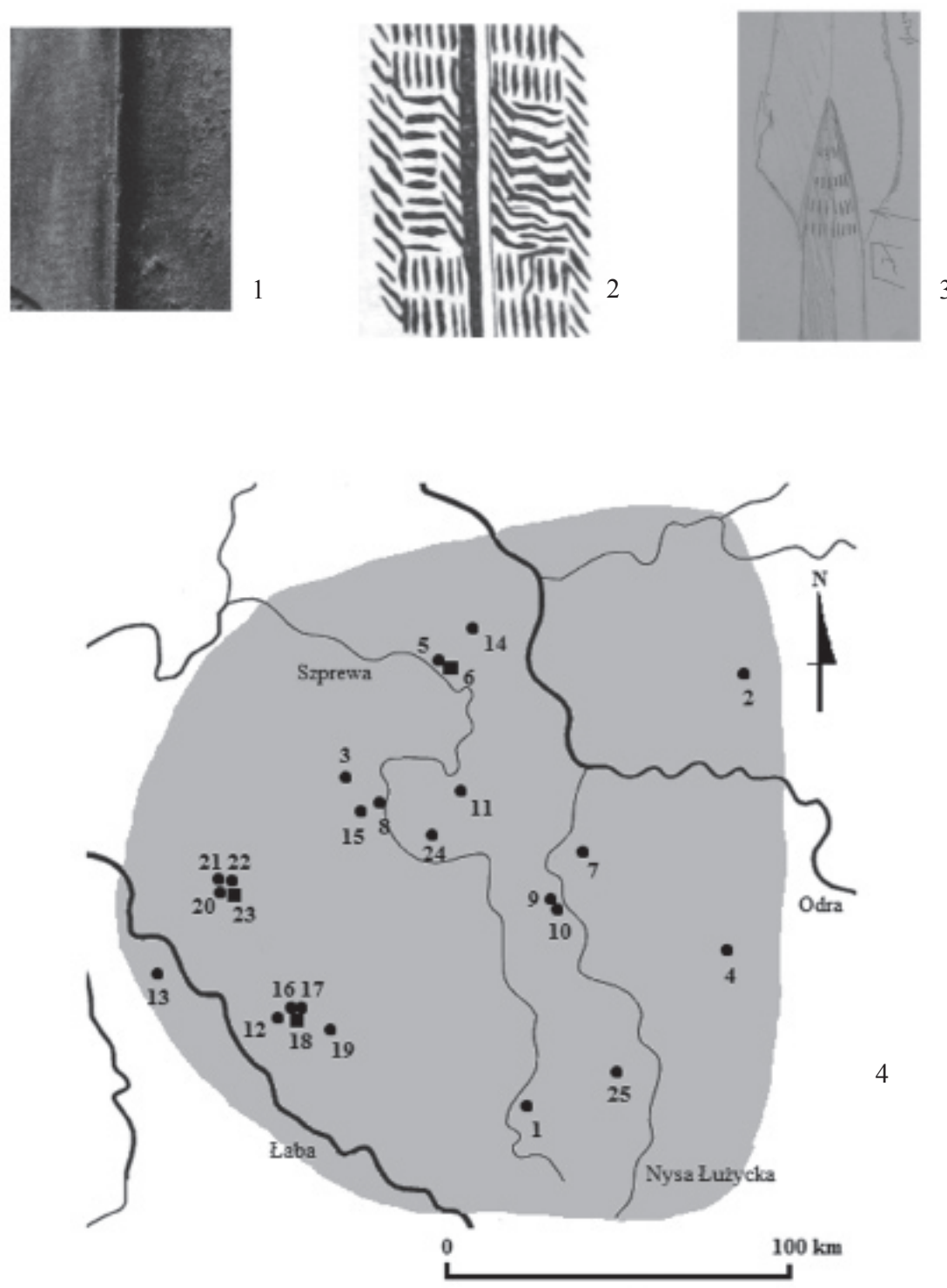

Tabl.IX: 1 - fragment ornamentu grotu z tzw. grobu 1 ze Stolzenhain, Lkr. Elbe-Elster; 2 - fragment ornamentu grotu ze Straupitz, Lkr. Dahme-Spreewald; 3 - fragment ornamentu grotu z Prieschka, Lkr. Elbe-Elster, 4 - rozmieszczenie grotów broni drzewcowej o cechach skandynawskich na terenie kultury luboszyckiej (punkty - groty bez zadziorów, kwadraty - groty z zadziorami; numeracja znalezisk zgodna z kolejnością katalogową) (Źródło: 1 - Schulz W. 1931: Taf. XIII.1; 2 - Weineck 1896: Fig. 5; 3 -Archiwum...; 4 - oprac. mapy autorzy) 